\title{
Economic uncertainty and bank stability: Conventional vs. Islamic banking
}

This draft: October 6, 2020

Preliminary version. Please do not quote without the permission of the authors

\author{
Mehmet Huseyin Bilgin \\ Faculty of Political Science, Istanbul Medeniyet University, Istanbul, Turkey \\ E-mail: bilginmh@gmail.com
}

\section{Gamze Ozturk Danisman}

Faculty of Management, Kadir Has University, Istanbul, Turkey

E-mail: gamze.danisman@khas.edu.tr

\section{Ender Demir}

Faculty of Tourism, Istanbul Medeniyet University, Istanbul, Turkey

E-mail: ender.demir@medeniyet.edu.tr

\begin{abstract}
Amine Tarazi
Université de Limoges, LAPE, 5 rue Félix Eboué, 87031 Limoges Cedex, France. \& Institut Universitaire de France (IUF), 1 rue Descartes, 75231 Paris Cedex 05, France E-mail: amine.tarazi@unilim.fr
\end{abstract}




\title{
Economic uncertainty and bank stability: Conventional vs. Islamic banking
}

\begin{abstract}
In this paper, we explore whether economic uncertainty differently affects the default risk of Islamic and conventional banks. Using a sample of 568 banks from 20 countries between 2009 and 2018, we take advantage of the World Uncertainty Index (WUI) proposed by Ahir et al. (2018) to conduct a study based on a comparable measure across countries. Our findings indicate that, while economic uncertainty increases the default risk of conventional banks, Islamic banks' default risk is not affected. To shed light on why economic uncertainty differently influences the default risk of Islamic and conventional banks, we explore the influence of religiosity, institutional factors and bank-level heterogeneity. We observe that Islamic banks' default risk is immune to uncertainty in all types of countries but that such a difference with conventional banks mainly holds for banks with higher non-interest income and larger size, and for banks which are publicly traded. Moreover, our findings show that conventional banks suffer more from uncertainty in terms of stability in countries with higher religiosity. Our results are robust to alternative estimation techniques to deal with endogeneity and to alternative variable measurements.
\end{abstract}

Keywords: Islamic Banks, Conventional Banks, Economic Uncertainty, Bank Stability, World Uncertainty Index

JEL Codes: G21, G28, G01, G32, D81

\section{Introduction}

The Islamic financial industry has experienced rapid growth in the last three decades. The global financial crisis of 2007-2009 and the rising uncertainty along with further globalization have contributed to the very fast development of Islamic banking in particular. Global Islamic banking assets increased from USD 1.3 trillion in 2012 to USD 1.76 trillion in 2018; and are expected to reach USD 2.175 trillion in 2024 (ICD-REFINITIV, 2020). Such trends have strongly attracted the attention of researchers and policy-makers; and many studies have explored Islamic banking, and specifically the differences between Islamic and conventional banks over the last decade (Beck et al., 2013a; Abedifar et al., 2015). A strand of this literature investigates whether Islamic banks are more financially stable than their conventional counterparts (Cihak and Hesse, 2010; Abedifar et al., 2013), especially during crisis periods (Hasan and Dridi, 2010; Beck et al., 2013a; Srairi, 2013).

While most of this literature has compared the stability of Islamic banks (IBs) and conventional banks (CBs), in this paper, we question whether their stability is differently affected by economic uncertainty, which is observed in both normal, and crisis times. Specifically, we aim 
to investigate whether fluctuations in uncertainty surrounding the economic environment are differently tackled by both types of banks possibly leading to different variations in their default risk. Uncovering such a channel is important because there are numerous factors that could lead to differences in behaviors and outcomes for the two types of institutions because of their different commitment vis-a-vis their borrowers and lenders.

In theory, the contracts and arrangements between the bank and its customers are very different for Islamic and conventional institutions both on the asset side and the liability side of the balance sheet. Specifically, the risk sharing principle between the bank and its borrowers, and between the bank and its depositors is expected to differently shape risk management practices and possibly lead to different outcomes. Moreover, uncertainty could differently influence both the demand and supply for banking products in an Islamic context compared to conventional banking. Such differences in behavior could be further enhanced by the extent of religiosity and the institutional environment.

For Islamic banks, the profit and loss sharing (PLS) principle and pass-through of risk between depositors and borrowers can be considered risk-reducing factors specifically when they endure difficult economic situations (Cihak and Hesse, 2010). Unlike CBs that charge a fixed interest rate on loans, IBs act as a "capital partner" and provide PLS loans in which the borrower pays back the principal and some agreed share of profits (or deductions in case of losses). Moreover, while depositors in conventional banking do not bear any risk as long as the bank is solvent, IBs, instead, channel investment deposits into PLS loans allowing any loss on the asset side to be absorbed not only by equity holders but also by the depositors who are generally referred to as investment account holders (IAH). Such PLS and risk-reducing mechanisms are expected, to some extent, to reduce the deterioration in IBs' net worth during difficult economic times (Cihak and Hesse, 2010; Bourkhis and Nabi, 2013). IBs' default risk could hence be less sensitive to changes in economic uncertainty compared to CBs. Moreover, due to the equitylike nature of savings and investment accounts, Islamic banks are closely monitored and disciplined by depositors, which mitigates moral hazard and adverse selection issues. In addition, IBs are generally more risk-averse and have a stronger preference for investing in the real economy. They are not allowed to perform risky and speculative trading activities. Such constraints could also make IBs less sensitive to changes in economic conditions compared to conventional banks. 
Nevertheless, the profit-loss sharing (PLS) principles to which Islamic banks need to abide by could also make them riskier (Abedifar et al., 2013). Indeed, PLS financing transfers credit risk from banks to depositors, but this leads to higher risk on the asset side of the balance sheet as it makes Islamic banks vulnerable to risks normally borne by equity investors rather than debtholders (Beck et al., 2013a; Cihak and Hesse, 2010). This equity-like financing can also decrease market discipline for Islamic banks. Furthermore, in terms of operational risk, Islamic banks face both legal and complex Sharia compliance risk (Beck et al., 2013a; Cihak and Hesse, 2010) while conventional banks are only prone to legal risk. The hedging capabilities are also lower for Islamic banks than for conventional banks as they are only allowed to use specific asset classes implying fewer risk-hedging instruments. Under difficult economic circumstances, CBs might better hedge their risks by using dedicated risk management techniques such as loan loss provisioning, collaterals, credit default swap, derivative instruments, etc. As Islamic banks generally operate on small scales compared to conventional banks, they might benefit less from economies of scale and portfolio diversification, which could increase their unsystematic risks.

Our work is related to a large strand of the literature, which compares the stability of Islamic banks and conventional banks (Sorwar et al., 2016), and from which no consensus can be drawn on whether one group is superior to the other in terms of stability (Cihak and Hesse, 2010; Rajhi and Hassairi, 2013; Srairi, 2013; Abedifar et al., 2013, Kabir et al., 2015; Pappas et al., 2017). Our work is also linked to papers comparing the performance of the two types of banks (Doumpos et al., 2017), their efficiency (Yudistra, 2004; Mobarek and Kalonov, 2014), and also the market power (Weill, 2011). Some of these papers focus on the comparison of risk during crisis periods such as Beck et al. (2013a) who show that even during the 2007-2009 global financial crisis, Islamic banks had higher asset quality and were better capitalized compared to conventional banks, leading to higher stock returns. However, other papers such as Alandejani et al. (2017) find that Islamic banks are more likely to fail by also considering the global financial crisis of 2007-2008; and therefore, survival time is shorter than conventional banks.

In this paper, we extend the literature by examining how economic uncertainty affects the default risk of Islamic and conventional banks. Economic uncertainty is present in both normal and crisis times, and can be measured in several ways, specifically with the Economic Policy Uncertainty (EPU) index constructed by Baker et al. (2016). Since its introduction, there is a rising interest in the literature to examine the impact of EPU on several financial and economic 
outcomes including stock returns, Bitcoin prices, real estate industry, growth, and oil prices. In the banking literature, several studies have examined the impact of EPU on non-performing loans (Karadima and Louri, 2020), credit growth (Bordo et al., 2016; Nguyen et al., 2020), credit risk (Chi and Li, 2017), bank valuations (He and Niu, 2018), banks' loan pricing (Ashraf and Shen, 2019), loan loss provisions (Ng et al., 2020), and bank stability (Phan et al., 2020).

Following the spirit of EPU, Ahir et al. (2018) introduce the "World Economic Uncertainty Index" (WUI) by counting the frequencies of the word "uncertainty" (and its variants) in the Economist Intelligence Unit (EIU) country reports. WUI can be considered as superior to EPU for cross-country studies because it is a standardized uncertainty measure across countries based on a single source. The WUI index globally peaks around the major uncertaintygenerating events such as the 9/11 attacks, the SARS outbreak, the Euro debt crisis, El Niño, the Brexit, the US presidential elections, and recently COVID-19 outbreak (Ahir et al., 2018). Another advantage of WUI is that it tracks economic uncertainty on a continuous basis and captures the fact that uncertainty is present in both normal and crisis times (Bilgin et al., 2020), which makes it a much more powerful indicator than using dummy variables. For example, using a dummy variable to capture the 2007-2009 global financial crisis, which is what most cross-country studies do, can be very limited when the sample countries exhibit strong economic heterogeneity. Figure 1 shows that uncertainty measured with WUI fluctuates significantly; and the values taken by this index can sometimes be higher during normal times than the crisis periods.

To explore how economic uncertainty affects the default risk of Islamic and conventional banks, this paper uses a sample of 568 banks from 20 countries between 2009 and 2018. To our knowledge, this is the first study to investigate the effects of economic uncertainty on bank default risk with a specific focus on possibly different outcomes for Islamic and conventional banks. Our findings indicate that economic uncertainty increases the default risk of conventional banks but that Islamic banks are immune to differences and/or changes in uncertainty. The results are robust to splitting the sample into Islamic and conventional banks, addressing endogeneity, and using alternative uncertainty index calculations. As documented by Bitar and Tarazi (2019), the current literature on Islamic and conventional banking is rather silent about endogeneity issues, and lacks exogenous instruments for examining bank stability. As a robustness check, we control for endogeneity by considering both the Two-Stage Least Squares (2SLS) instrumental variable (IV) and the Generalized Method of Moments (GMM) 
techniques and our results remain robust. For deeper insights, we also decompose default risk into asset risk and leverage risk and find that our results are mainly driven by leverage risk, which is significantly affected by economic uncertainty for conventional banks but not for Islamic banks. To shed light on why economic uncertainty influences the default risk of Islamic and conventional banks rather differently, we also consider the influence of religiosity and institutional factors. Our results pointing to the absence of sensitivity of default risk to changes in uncertainty for Islamic banks but not for conventional banks are stronger for highly religious countries. With regard to the impact of the institutional environment, our findings reveal that the differential impact of fluctuations in economic uncertainty on the stability of both types of banks is only observed in countries that implement Common English law and are in GCC and richer. Further, cross-sectional analyses show that the main findings hold for banks with higher non-interest income (both trading oriented and commission and fee-oriented ones), larger size, and the listed ones.

The rest of the paper is organized as follows. Section 2 presents our data, variables, and methodology. Section 3 discusses the empirical findings of the study. Section 4 concludes the paper and provides policy implications.

\section{Data and Methodology}

We first present the data used in this study, and then the variables and our baseline econometric specification to capture the impact of uncertainty on Islamic banks' stability as compared to conventional banks' stability.

\subsection{Data sources and sample construction}

The data for bank-level variables is retrieved from the Fitch Connect database with data on both listed and non-listed banks. Following Beck et al. (2013b), we use unconsolidated data when available; if not, we use consolidated data to avoid double counting of subsidiaries. We form our initial sample focusing on the 2009-2018 period; and we find data for 120 Islamic banks and 585 conventional banks from 23 countries where both Islamic and conventional banking operate alongside each other. In order to reach our final sample, we follow the filtration used by Mollah et al. (2017) and Beck et al. (2013a). Specifically, we filter the sample by excluding the countries with fewer than four banks and fewer than three years of consecutive data. After 
filtering, our final sample corresponds to 568 banks (82 Islamic, 486 conventional) from 20 countries between 2009 and 2018. Table A1 in the Appendix presents the list of countries and their respective number of Islamic vs. conventional banks.

WUI, the world uncertainty index, is the key independent variable of interest in our analysis. We collect the data for WUI from Ahir et al. (2018) who developed the index by counting the frequencies of the words related to "uncertainty" in the Economist Intelligence Unit (EIU) country reports. The EIU reports cover the political and economic developments in each country alongside future policy-related and economic projections. The raw counts of "uncertainty" are scaled by the number of words in each report, which makes the index comparable across countries $^{1}$.

The data for macroeconomic variables such as GDP growth, inflation, oil and mineral rents are obtained from World Bank World Development Indicators. Financial and institutional development indicators are retrieved from numerous sources such as World Bank Global Financial Development Database, Pew Research Center (2009), Djankov et al. (2007), CIA's World Fact Book, and World Values Surveys (WVS).

\subsection{Variables and empirical methodology}

Following the extant literature on Islamic banking (Bitar and Tarazi, 2019; Abedifar et al., 2013; Mollah et al., 2017; Mollah and Zaman, 2015), the baseline estimations are conducted using random effects, and Generalized Least Square (GLS) regressions. GLS is implemented due to the following two reasons. First, regression techniques such as Ordinary Least Squares (OLS) would not account for the panel dimension of the data. Second, one of our main independent variables is a time-invariant dummy variable for Islamic banks, which cannot be straightforwardly estimated using fixed effect estimation techniques ${ }^{2}$. We use the following empirical model in our baseline estimations:

Bank risk $_{i j t}=\beta_{0}+\beta_{1} I_{S L A M I C}+\beta_{2} * \operatorname{LnWUI}_{j t}+\beta_{3} * \operatorname{LnWUI}_{j t} * \operatorname{ISLAMIC}_{i}+$ $\beta_{4}$ Bank Controls $_{i j t-1}+\beta_{5}$ Country Controls $_{j t-1}+\beta_{t}+\varepsilon_{i j t}$

\footnotetext{
${ }^{1}$ A detailed presentation of WUI can be retrieved from https://worlduncertaintyindex.com/.

${ }^{2}$ We performed the Hausman test, and the results confirm that random effects are better with an insignificant test statistic and of magnitude 31.37 .
} 
where $\mathrm{i}, \mathrm{j}$ and $\mathrm{t}$ stand for bank, country, and time, respectively. Following Bitar and Tarazi (2019) and Beck et al. (2013a), standard errors are clustered at the bank level instead of the country level, because some countries in the sample have more observations than others and clustering at the country level with twenty countries might potentially distort the results. $\beta_{t}$ stands for time fixed effects, and $\varepsilon_{i j t}$ indicates unobserved error terms. Bank and country controls are lagged by one year to mitigate endogeneity concerns, considering that it might take more than one year for these variables to influence bank stability. We eliminate the outliers in bank-specific variables by winsorizing at $1 \%$ and $99 \%$ levels.

In addition to random effects Generalized Least Square (GLS) regressions, we also use dynamic panel data techniques with the two-step system GMM estimators and IV regressions with 2SLS estimators to deal with potential endogeneity. For this purpose, we use the following dynamic model:

Bank risk $_{i j t}=\beta_{0}+\beta_{1} *$ Bank risk $_{i j t-1}+\beta_{2} *$ LnWUI $_{j t}+\beta_{3}$ Bank Controls $_{i j t-1}+$ $\beta_{4}$ Country Controls $s_{j t-1}+\beta_{t}+\varepsilon_{i j t}$

Table 1 displays the brief descriptions of all bank-specific and country-specific variables used in our analysis. Bank risk in Equations 1 and 2 corresponds to bank stability measures where the main dependent variable is bank default risk (DEFAULT RISK), proxied by the Z-score. Z-score measures the soundness of banks, and is widely used as a bank stability measure in the banking literature (Agoraki et al., 2011; Beck et al., 2013b; Bourkhis and Nabi, 2013). It is calculated as $z=\frac{(R O A+C A P I T A L I Z A T I O N)}{S D(R O A)}$ where $R O A$ indicates the return on assets, CAPITALIZATION is the share of equity in total assets. $S D(R O A)$ is the standard deviation of ROA calculated using three-year rolling windows. As the formula clearly indicates, the Z-score can be interpreted as the number of standard deviations that ROA should drop below its expected value before equity is depleted; and it is inversely related to the probability of a bank's insolvency. Our measure in the analysis, DEFAULT RISK, is calculated as the negative of the natural logarithm of Z-score so that higher values indicate a higher risk. Table 2 presents descriptive statistics for the full sample as well as for Islamic and conventional banks and shows that DEFAULT RISK varies from -8.01 to 0.13 , with an average of -3.99 . Univariate comparisons with two-sided t-tests between Islamic and conventional banks in Table 2 reveal 
that Islamic banks and conventional banks do not, on average, exhibit significant differences in DEFAULT RISK. Table A2 in the Appendix presents descriptive statistics at the country level for the main variables that are used in the baseline estimations. The highest average DEFAULT RISK is observed in Iran, which is followed by Yemen and Sudan. Meanwhile, Singapore, Saudi Arabia and Malaysia rank at the bottom with the lowest averages.

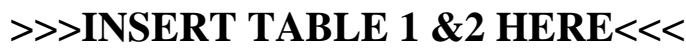

We further decompose the Z-score into its two components (Goyeau and Tarazi, 1992; Lepetit et al., 2008a; Barry et al., 2011) for deeper insights and a better understanding of what is mainly driving default risk or what is specifically affected by economic uncertainty. The first component is LEVERAGE RISK, which is the negative of the natural logarithm of the ratio of CAPITALIZATION to SD(ROA). The second component is the PORTFOLIO RISK calculated as the negative of the natural logarithm of the ratio of ROA to $\mathrm{SD}(\mathrm{ROA})$. Table 2 indicates that Islamic banks have a significantly higher PORTFOLIO RISK as compared to conventional banks; however, no significant difference can be observed for the LEVERAGE RISK. Moreover, Table 2 shows descriptive statistics on two components of the Z-score, ROA and CAPITALIZATION (equity to total assets). Islamic banks have a significantly lower ROA on average but a significantly higher CAPITALIZATION compared to conventional banks. ISLAMIC in Equation 1 is a dummy variable equal to 1 for Islamic banks and 0 for conventional banks. As displayed in Table 2, Islamic banks represent $14 \%$ of the banks in our sample.

We use the country-specific world uncertainty index following Bilgin et al. (2018) and Jones and Sackley (2016), we transform it by taking its natural logarithm. The index is available on a quarterly basis; and since our analysis requires yearly variables, we use the simple average of the four quarters and generate a yearly variable. We then take the natural logarithm of this mean and call the transformed variable WUI for brevity. Table 2 indicates that WUI ranges from 4.05 to -0.29 with an average of -2.15 . As apparent from the within-country and betweencountry standard deviations, while WUI shows substantial variation both over time and across countries, variation over time is higher. Table A2 shows that the highest average WUI is from Turkey, followed by Lebanon and Tunisia. The lowest average WUI is from Qatar, followed by Bangladesh. We further consider alternative calculation methods to compute our yearly WUI measure for robustness checks. While WUI_V2 is the natural logarithm of the average quarterly 
country-specific WUI index, it is calculated using the three-quarter weighted moving average. ${ }^{3}$ WUI_V3 is the natural logarithm of the average of only the first two-quarters of countryspecific WUI. WUI_V3, in fact, incorporates the lagged effect of WUI. We further include an interaction term between WUI and ISLAMIC in Equation 1 to examine whether Islamic banks' risk is differently affected by economic uncertainty from their conventional counterparts.

Bank Controls stand for bank-specific indicators of bank stability, which are chosen following the extant literature (Beck et al., 2013; Abedifar et al., 2013). They include the natural logarithm of total assets (SIZE), annual growth of total assets (GROWTH), net loans to total assets (LOAN SHARE), non-interest income/gross revenues (NON-INTEREST INCOME). From Table 2, we observe that Islamic banks have a significantly higher NON-INTEREST INCOME compared to conventional banks. For deeper insights, we also use COMMISSION and TRADING. COMMISSION is the share of net fees and commissions in non-interest income and that the average of COMMISSION is $53.80 \%$ in the overall sample. TRADING is calculated as the share of net trading and derivatives in non-interest income and its mean value is $12.87 \%$ in the overall sample. We also consider liquid assets to total assets (LIQUIDITY), the share of total costs in total income (COST TO INCOME), and LISTED, a dummy variable equal to 1 for publicly listed banks and 0 otherwise. Table 2 shows the COST TO INCOME is higher for Islamic banks than conventional banks. $41 \%$ of the banks in our overall sample are listed. $42 \%$ of conventional banks and $34 \%$ of Islamic banks are listed. The t-tests reveal that conventional banks are significantly more often listed than Islamic banks.

Country controls stand for macro-economic and financial development variables. They include real GDP growth rate (GDP GROWTH), inflation rate (INFLATION), and oil and mineral rents as a share of GDP (OIL MINERAL). In addition, we use foreign banking share in total assets (FOREIGN BANK ASSETS) and the share of total assets of the three largest banks in total assets (CONCENTRATION). Table A2 indicates that there is a wide variation of countrycontrols across countries, confirming that it is relevant to control for these effects in our analysis.

\footnotetext{
${ }^{3}$ As an example, the three-quarter weighted moving average of the World Uncertainty Index is calculated for 2012Q4 as follows: $2012 \mathrm{Q} 4=[(2012 \mathrm{Q} 4 * 0.6)+(2012 \mathrm{Q} 3 * 0.3)+(2012 \mathrm{Q} 2 * 0.1)] / 3$. For details, please refer to https://worlduncertaintyindex.com/.
} 
In extended analyses, we use additional country controls, which include MUSLIM SHARE, COMMON LAW, CIVIL LAW, LEGAL SYSTEM and IMPORTANCE OF RELIGION. MUSLIM SHARE is the share of the Muslim population in each country; and it is extracted from the Pew Research Center (2009) ${ }^{4}$. Table 2 indicates that the average share MUSLIM SHARE in our sample countries is $84.87 \%$. COMMON LAW and CIVIL LAW are indicator variables that equal 1 for the English common law and French civil law legal origin countries, respectively, and 0 otherwise, with data from Djankov et al. (2007). 36\% of the countries in our sample implement common law. LEGAL SYSTEM is an indicator variable that takes a value of 0 if the country does not have Shari'ah law in its legal system, the value 1 for countries that consider Shari'ah together with other legal systems and 2 if the legal system is based exclusively on Shari'ah law. The data on legal systems is taken from the CIA's World Fact Book $^{5}$. Finally, IMPORTANCE OF RELIGION corresponds to the share of the population that considers religion to be very important with data gathered from World Values Surveys (WVS). Table 2 shows that, on average, $90.77 \%$ of the population in the countries consider religion to be very important. Table A3 shows correlation coefficients between exogenous variables and indicate no major collinearity problems.

\section{Results}

We first present the baseline regression results, and then the findings of our further investigations.

\subsection{Baseline regressions}

We present the main regression results in Table 3, which uses the full sample of banks. The estimations are conducted using random effects, Generalized Least Square (GLS) regressions. We use Equation 1 and include the Islamic bank dummy (ISLAMIC) and the interaction term between WUI and ISLAMIC in all model specifications in order to investigate differences in this relationship between Islamic vs conventional banks. The Wald Chi2 tests are significant for all models; and R-squared values are relatively high in line with the previous literature (Bitar and Tarazi, 2019; Houston et al., 2010). Model 1 uses DEFAULT RISK as a dependent

\footnotetext{
${ }^{4}$ The report can be reached at https:/www.pewforum.org/2009/10/07/mapping-the-global-muslim-population/
} 
variable; and Models 2 and 3 decompose the Z-score into its two components and use LEVERAGE RISK and PORTFOLIO RISK as dependent variables. The positive and significant coefficient for WUI in Model 1 indicates that an increase in WUI significantly increases bank default risk for conventional banks. Exploring the reaction of Islamic banks to changes in uncertainty, we observe that while the coefficient of WUI is positive and significant, the coefficient of the ISLAMIC*WUI is significantly negative. As presented in Table 3, the overall effect captured by the non-significance of the sum of the coefficients of WUI and ISLAMIC*WUI indicates that Islamic banks are immune to changes in uncertainty. Models 2 and 3 decompose the DEFAULT RISK, Z-score, into its two components LEVERAGE RISK and PORTFOLIO RISK and we observe that our previous findings are driven by LEVERAGE RISK but not by PORTFOLIO RISK. While uncertainty increases the leverage risk of conventional banks, the effect of uncertainty on Islamic banks' leverage risk is not significant, which explains why they are unaffected by uncertainty. Model 4 uses FOREIGN BANK ASSETS and CONCENTRATION as two additional country controls, and our results remain robust. Model 5 uses dynamic panel data techniques with two-step system GMM estimators to address endogeneity concerns; and lagged DEFAULT RISK is included as an independent variable. Following the extant literature, while the lagged dependent variable and the bankspecific controls are considered predetermined and instrumented like GMM-style, macroeconomic variables are taken as exogenous and instrumented by themselves (Roodman, 2009). We perform various specification tests to validate our GMM estimation, including the Arellano-Bond AR(1) and AR(2) tests for the first and second-order autocorrelation of the residuals and the Hansen test of over-identifying restrictions. The coefficients of the tests are displayed at the bottom of Table 3, confirming a valid specification and reliable model. Specifically, the AR(2) and Hansen tests are not significant in line with expectations, showing that there is no second-order autocorrelation among errors; and over-identifying restrictions are valid, respectively. Therefore, our main findings remain robust under GMM estimation. Models 6 and 7 use alternative WUI measures: WUI_V2 and WUI_V3, respectively, using random effects, Generalized Least Square (GLS) regressions. Our results remain robust under these alternative WUI specifications.

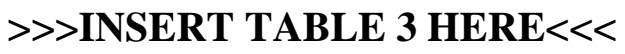

With regard to bank-level control variables, many of them are significant with the expected signs. We observe that banks with higher loan shares are less risky. Moreover, banks with a 
higher cost to income ratios and non-interest income and higher growth are riskier. Regarding the country controls, higher inflation has a positive impact on bank risk and higher oil and mineral rents have a negative impact. Moreover, higher foreign bank dominance increases bank risk.

Next, for robustness checks, Table 4 displays the WUI- bank default risk regressions for separate samples of Islamic and conventional banks using DEFAULT RISK as the dependent variable. Models 1 and 2 are conducted for Islamic and conventional bank subsamples, respectively, using random-effects Generalized Least Square (GLS) regressions. The findings are in line with our previous ones indicating that in the presence of higher uncertainty, the default risk of conventional banks is significantly higher, which does not apply to Islamic banks. This lack of a significant association between uncertainty and bank default risk for Islamic banks confirms that Islamic banks are immune to changes in uncertainty. Models 3 and 4 in Table 4 use IV estimation techniques to account for potential endogeneity. As stated by Bitar and Tarazi (2019), the current literature on Islamic and conventional banking is rather silent about endogeneity issues and lacks exogenous instruments for examining bank risk-taking. Considering the potential endogeneity that might be due to uncertainty spurred by banking system fragility, we re-estimate our regressions by considering the 2SLS instrumental variable approach. Following Jeon et al. (2020) and Baker and Bloom (2013), we use the following instruments for WUI. First, for each country, we use its largest export market country's WUI index. Second, we utilize, for each country, their foreign direct investment (FDI) inflow partner country's WUI index. ${ }^{6}$ The underlying assumption is that the uncertainties in their major export partners and biggest foreign investor countries would generate a contagious effect and induce an increase in the country's own uncertainty. However, the riskiness of banks is less likely to be directly affected by uncertainties in such countries (Jeon et al., 2020). Third, following Baker and Bloom (2013), we use political shocks and high casualty terrorist attacks as IVs. Political shocks are defined as a dummy variable equal to 1 for the periods of successful and attempted (failed) coups and the resignation of national leadership due to the loss of authority; 0 otherwise. High casualty terrorist attacks are defined as the terrorist bombings that cause more than 15 deaths. It is generated as an indicator variable from 1 to 6 , showing the magnitude of the attack. The data for political shocks and high casualty terrorist attacks are taken from Baker and Bloom (2013) and the Center for Systemic Peace. As a final IV, we use the lagged first-order difference

\footnotetext{
${ }^{6}$ Major export market data is extracted from the Observatory of Economic Complexity website (https://oec.world/en/) and major sources of FDI data is from UNCTAD Statistics.
} 
of WUI. Our results are displayed in Table 4 Models 3 and 4. The Kleibergen and Paap (2006) LM under-identification test, reported at the bottom of Table 4, shows that the instruments are valid and are jointly relevant to explain WUI. Moreover, the Hansen J-statistics, an overidentification test, reveals that instruments are not correlated with the error term. The coefficient of WUI is positive and significant for conventional banks but not significant for Islamic banks, generating additional supportive evidence for earlier findings.

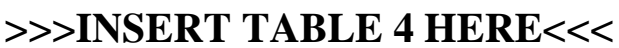

\subsection{Additional analyses on the influence of religiosity and institutional environment}

To shed light on why economic uncertainty influences the default risk of Islamic and conventional banks rather differently, we follow Mollah et al. (2017) and Bitar and Tarazi (2019), and extend the baseline regressions by considering the influence of religiosity and the institutional environment of the countries. We first evaluate the influence of religiosity of the countries by splitting the sample into Muslim majority (MUSLIM SHARE+90) vs non-Muslim majority (MUSLIM SHARE-90) populations; High vs. Low IMPORTANCE OF RELIGION; and Sharia law vs non-Sharia law countries (Table 5). Models 1 and 2 in Table 5 present the findings for MUSLIM SHARE+90 vs MUSLIM SHARE-90 countries. Following Abedifar et al. (2013) and Abedifar et al. (2016), Muslim majority countries in our analyses correspond to the countries that have more than $90 \%$ share of Muslim population. The results indicate that WUI, ISLAMIC and ISLAMIC*WUI variables are significant and with similar signs as in our baseline regressions only for MUSLIM SHARE+90 countries (Models 1 and 2 in Table 5). The magnitudes of the coefficients are also higher. Therefore, the differential impact of fluctuations in economic uncertainty on the stability of both types of banks is only observed in countries with a relatively high representation of Muslim population. In countries with a lower proportion of Muslims, uncertainty does not affect the stability of either IBs or CBs. Such a result suggests that the observed immunity of IBs to uncertainty in the baseline regression could be explained by the role played by religion, and specifically higher trust and stronger links between the banks and their customers. In countries with a lower proportion of Muslims, such a contrast between Islamic banks and conventional banks is not prevalent possibly because such effects could be diluted. 
The strong role played by religion is confirmed by Models 3 and 4, which display results for another dimension of religion (how strongly it is followed by the population) (IMPORTANCE OF RELIGION). Following Bitar and Tarazi (2019), high importance corresponds to values taken by this variable, IMPORTANCE OF RELIGION, above the 75th percentile in our analysis $^{7}$. The results in columns (3) and (4) show that where religion is considered less important, all banks are sensitive in terms of stability and both CBs and IBs suffer from higher uncertainty. Conversely, where religion is important, stability is negatively impacted by uncertainty only in the case of CBs. IBs' default risk is immune to changes in uncertainty.

Models 5 and 6 in Table 5 conduct the analysis for Shariah law vs. non-Sharia law countries. We consider Shariah law countries as the ones implementing either exclusively Shariah law in their legal systems or Shariah law together with other legal systems. This corresponds to countries for which the variable LEGAL SYSTEM takes values of 1 and 2. Non-Sharia law countries correspond to the ones for which LEGAL SYSTEM takes a value of 0. Our main findings only hold for countries that implement Shariah law either exclusively or alongside with other legal systems. In other countries, default risk is not influenced by uncertainty, neither for IBs nor for CBs. This is comparable to the results displayed in columns (1) and (2); and again it suggests that bank customers adopt a different behavior towards CBs and IBs only in highly religious countries. In less religious countries, neither CBs nor IBs suffer from lower stability when uncertainty is higher. We perform robustness checks in Table A4 where we conduct subsample estimations and estimate the regressions for IBs and CBs separately. Our findings are consistent with the previous ones: the differential impact of fluctuations in economic uncertainty on the stability of both types of banks is observed only in highly religious countries with Muslim majority populations (MUSLIM SHARE+90), where religion is important (IMPORTANCE OF RELIGION: High), and that implement Shariah law.

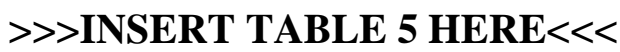

Next, we further extend the baseline regressions in Table 6 and consider the influence of the institutional environment in the countries by splitting the sample into COMMON LAW vs CIVIL LAW countries; GCC vs. Non-GCC countries; and Rich vs. Poor countries. The results indicate that, while Islamic banks are immune to uncertainty in all types of countries,

\footnotetext{
${ }^{7}$ The 75 th percentile for the IMPORTANCE OF RELIGION in our sample is $94 \%$.
} 
conventional banks suffer more from a negative impact of uncertainty in terms of stability in the case of common law as opposed to civil law countries (models $1 \& 2$ in Table 6 ) and in Gulf Cooperation Countries (GCC) ${ }^{8}$ as opposed to other countries (models $3 \& 4$ in Table 6 ) as shown by higher coefficient estimates. Finally, Models $5 \& 6$ in Table 6 distinguish the richer and poorer countries where rich countries correspond to the ones with real GDP per capita above the median; ${ }^{9}$ and poor countries are the ones with real GDP per capita below the median, respectively. It is observed that our previous findings are mainly relevant for richer countries. In poorer countries, neither Islamic nor conventional banks are impacted by uncertainty in terms of default risk. We perform robustness checks in Table A5 by estimating the regressions for sub-samples of IBs and CBs separately. In line with our previous results, the two types of banks behave differently in terms of stability for the common law, GCC and richer countries.

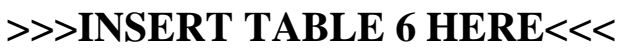

Overall, our main finding indicates that only conventional banks are negatively affected by uncertainty, as Islamic banks are immunized. This is stronger or mainly prevalent under the following country groups: (1) MUSLIM SHARE+90 (Muslim population share>90\%), (2) High IMPORTANCE OF RELIGION, (3) Sharia law, (4) COMMON LAW, (5) GCC countries, and (6) Rich countries.

\subsection{Bank-level heterogeneity}

Next, to go deeper into our understanding of why Islamic and conventional banks' default risk is differently influenced by economic uncertainty, we explore bank-level heterogeneity by focusing on specific bank-level characteristics. We explore the role played by non-interest activities (i.e. non-traditional, activities other than lending), bank size, and whether the banks are listed or not on a stock exchange (see Table 7). Specifically, Models $1 \& 2$ split the banks into high vs low NON-INTEREST INCOME; ${ }^{10}$ Models 3 and 4 decompose the High NONINTEREST INCOME subsample into trading oriented and commission and fee-oriented

\footnotetext{
${ }^{8}$ GCC countries in the sample correspond to Kuwait, Qatar, Saudi Arabia and the United Arab Emirates.

${ }^{9}$ The median for real GDP per capita (with 2010 constant USD) in our sample is 4,120.429 USD.

${ }^{10}$ High vs low NON-INTEREST INCOME subsamples are generated using the banks that have greater and smaller non-interest income in gross revenues than the median score of $27.63 \%$. For robustness, we also consider Q25 and Q75 instead of the median (below Q25 and above Q75) and obtain similar findings. The results are available upon request.
} 
banks; ${ }^{11}$ Models $5 \& 6$ split the samples according to the size of banks as large vs small; ${ }^{12}$ and Models $7 \& 8$ present the findings for listed and non-listed banks, respectively ${ }^{13}$. We observe substantial differences under these settings. ${ }^{14}$ A quick glance at the results shows that our main findings only hold for banks with a higher share of NON-INTEREST INCOME (both trading oriented and commission and fee oriented), large banks, and LISTED ones. Only such Islamic banks exhibit a different reaction in terms of stability from their conventional peers. For the other types of banks, there's no significant difference in terms of default risk sensitivity to changes in uncertainty. Specifically, the fact that non-interest income plays, in our setting, a major role in terms of sensitivity of default risk to uncertainty changes is not surprising. The NON-INTEREST INCOME (the share of non-interest income in gross revenues) shows the extent of diversification and includes revenues from sources other than interest such as net gains on trading activities, and commissions and fees. Overall, such activities capture how much banks rely on nontraditional activities other than lending. Nevertheless, such activities also include fees directly or indirectly related to lending activities and possibly to a larger extent for Islamic banks, for which explicit interest cannot be charged on loans. The findings from Models $1 \& 2$ of Table 7 show that the coefficient estimate of the WUI variable is significant only for banks with High NON-INTEREST INCOME, revealing that only CBs highly diversified away from strictly traditional interest activities are negatively affected by uncertainty. Such a finding is in line with the literature showing that income diversification through replacing traditional lending activities with trading, derivatives and commission and fee-based activities is associated with higher earnings volatility and risk (DeYoung and Roland, 2001; Lepetit et al., 2008a; Meslier et al., 2014). Such non-traditional activities suffer from uncertainty, and hence make CBs more vulnerable and less resilient under such circumstances. However, the situation is rather different for IBs. In Model 1, the non-significance of the sum of the coefficients of

\footnotetext{
${ }^{11}$ The "High Non-interest Income-Trading oriented" subsample in Column 3 is created taking the intersection of high non-interest income share banks (in Column 1) and banks with a high share of trading activities in noninterest income (above the median). The "High Non-interest Income-Commission and Fee Oriented" subsample in Column 4 is created similarly. We implement robustness checks by using Q25 and Q75 instead of the median (below Q25 and above Q75) and obtain similar findings. The results are available upon request.

12 Large vs small banks subsamples are generated using the observations greater and smaller than the median of the log of total assets which is 7.63 (corresponding to 2.06 Billion USD). We also use Q25 and Q75 instead of the median (below Q25 and above Q75) and similar findings are observed.

${ }^{13}$ To make sure we have enough observations of both IBs and CBs in these subsamples, we calculated the share of IBs in the total number of banks for each of these subsamples. The average share of IBs in these subsamples is between $13 \%$ and $17 \%$, which is similar to our overall sample distribution (the share of IBs in the overall sample is $14 \%$ ).

${ }^{14}$ For the concerns of overlapping subsamples, (such as large banks being the more diversified and listed ones), we calculated the number of observations for each subsample. The subsamples of high vs low non-interest income do not overlap with large vs. small banks. Nevertheless, listed banks are observed to be generally larger. The results are available upon request.
} 
WUI and ISLAMIC*WUI, and a significantly negative coefficient estimate of the ISLAMIC dummy reveals that IBs with high non-interest income are not only immune to uncertainty, but uncertainty also reduces their default risk. In Models 3 and 4, we go deeper and investigate which types of non-interest activities make CBs more vulnerable. For that purpose, as in Lepetit et al. (2008a, 2008b), we first disaggregate the NON-INTEREST INCOME into its components: COMMISSION and TRADING. We then take the intersection of High NONINTEREST INCOME and banks with a high share of TRADING and COMMISSIONS, and form "High NON-INTEREST INCOME-Trading Oriented" and "High NON-INTEREST INCOME- Commission and Fee-Oriented" subsamples (Models 3\&4). The coefficient estimates of the WUI variable are significant for both Models $3 \& 4$, showing that when uncertainty goes up, regardless of how they are diversified (either mainly into trading activities or mainly into commission and fee activities), conventional banks always suffer from higher uncertainty. For commission and fee activities, the absence of impact on stability for IBs happens possibly because such an income is linked to their on-balance sheet activities such as loans. For trading activities, the fact that Islamic banks are not affected could be due to the nature of their trading portfolios, which is presumably different due to restrictions imposed by Sharia boards. Moreover, activities such as trading, derivatives and commissions\& fee income are generally less developed for IBs as compared to $\mathrm{CBs}^{15}$.

Regarding heterogeneity in bank size (Model 5 in Table 7), we observe that while large CBs suffer from uncertainty in terms of stability, large IBs are immunized. For small banks, Model 6 shows that default risk is not significantly associated with uncertainty, either for IBs or CBs. With regard to the differences between LISTED and non-LISTED banks (Models $7 \& 8$ ), we observe that while conventional listed banks are negatively affected by uncertainty, Islamic listed banks are immunized. However, in the case of non-listed banks, neither CBs nor IBs suffer from uncertainty. In our sample, listed banks are generally observed to be larger. ${ }^{16}$ Thus, our findings could be explained by the fact that the bank-customer relationship is tighter in small banks, which have a comparative advantage in terms of soft information processing (Berger et al., 2005; Berger and Black, 2011). For small banks, the bank type matters less for stability under uncertainty and both types of banks (IBs and CBs) will continue to support their

\footnotetext{
15 Table 2 shows that while the average of COMMISSIONS is $52.31 \%$ for IBs, it is higher for CBs (54.05\%). Similarly, the mean value of TRADING is $11.03 \%$ for IBs and $13.11 \%$ for CBs.

${ }^{16}$ For the listed banks in our sample, $68 \%$ of them are categorized as large and $32 \%$ are small. Note that large and small banks are defined using the observations greater and smaller than the median of SIZE which is defined as the natural logarithm of total assets.
} 
customers. But for large banks, the bank-customer relationship is weaker for large CBs, and they are characterized by hard information. Thus, the impact of fluctuations in uncertainty on large CBs' stability is more prevalent as compared to large IBs. We perform several robustness checks presented in the Appendix (Table A6). We estimate the regressions on subsamples of IBs and CBs separately for High vs Low NON-INTEREST INCOME ${ }^{17}$ in Models 1-4, for High NON-INTEREST INCOME- Trading Oriented vs. High NON-INTEREST INCOMECommission and Fee Oriented in Models 5-8, large vs small banks in Models 9-12, and LISTED and non-LISTED banks in Models 13-16, respectively. Our main findings remain unchanged. ${ }^{18}$

\section{>> INSERT TABLE 7 HERE $<<<~$}

\section{Conclusion and Policy Implications}

We examine whether economic uncertainty differently influences the default risk of Islamic and conventional banks. Economic uncertainty is proxied by the World Uncertainty Index (WUI) proposed by Ahir et al. (2018). We find that a rise in economic uncertainty leads to an increase in the default risk of conventional banks implying lower stability. However, the default risk of Islamic banks is immune to differences and/or changes in uncertainty. The results are robust to splitting the sample into Islamic and conventional banks, addressing endogeneity (GMM and IV estimations), and using alternative uncertainty index measures. After decomposing default risk, we find that uncertainty increases the leverage risk of conventional banks, while the effect on Islamic banks' leverage risk is not significant which explains why they are unaffected by uncertainty. We conclude that the different impact of economic uncertainty on CBs and IBs are driven by leverage risk but not by portfolio risk.

\footnotetext{
${ }^{17}$ We use the within sub-sample medians instead of overall sample medians to generate high vs. low noninterest and large vs. small subsamples, respectively.

${ }^{18}$ After finding that the results are stronger for the following three groups of banks (High non-interest income share, large and listed banks), we further investigate the influence of religiosity and institutional environment for these three groups separately for which we document different behavior for IBs and CBs. Our main findings (CBs are negatively affected by uncertainty while IBs are not), are still stronger for Muslim majority countries, the countries that implement Sharia law and where the importance of religion is high, Common law, GCC, and richer countries). The results of these estimations are available upon request.
} 
To examine why economic uncertainty differently influences the risk of Islamic and conventional banks, we consider the influence of religiosity and institutional factors. We show that the different impact of economic uncertainty on the stability of both types of banks is only observed in Muslim majority countries. In countries with a lower proportion of Muslim population, uncertainty does not affect the stability of either IBs or CBs. The strong role of religion is confirmed once we use another dimension of religion, namely the importance of religion. In countries where religion is important, the default risk of conventional banks is negatively affected by economic uncertainty while IBs' default risk is immune to changes in uncertainty. The immunity of IB's default risk to uncertainty also holds for countries that implement Shariah law either exclusively or alongside other legal systems. In terms of the influence of the institutional environment, the default risk of two types of banks differs in common law countries, Gulf Cooperation Countries and richer countries.

Moreover, we go deeper into our understanding of why Islamic and conventional banks' default risk is differently influenced by economic uncertainty by exploring bank-level heterogeneity. We do so by focusing on the role played by non-interest activities, bank size, and bank stock market quotation. Our main finding only holds for banks with a higher share of non-interest income (both trading oriented and commission and fee oriented), large banks and listed ones. Only such Islamic banks exhibit a different reaction in terms of stability from their conventional peers.

Our findings for the case of conventional banks are in line with Phan et al. (2020) who show that uncertainty (as measured by EPU) is harmful to bank stability. We, however, show that, under certain conditions, Islamic banks are immune to uncertainty. Our findings have several policy implications. Regulatory bodies and governments should be aware of the differential effect of uncertainty on conventional banks' and Islamic banks' default risk, especially regarding the leverage risk component. According to our findings, a dramatic rise in uncertainty can cause severe instability in the banking industry but with a weaker impact in dual banking markets where both types of banks operate alongside each other. Also, because conventional banks are more affected than Islamic banks, regulators might need to take stronger action in terms of recapitalization for conventional banks than for Islamic banks. It is indeed conventional banks' leverage risk which is the most affected by higher uncertainty. 


\section{References}

Abedifar, P., Molyneux, P., \& Tarazi, A. (2013). Risk in Islamic banking. Review of Finance, 17(6), 2035-2096.

Abedifar, P., Ebrahim, S.M., Molyneux, P. and Tarazi, A., 2015. Islamic banking and finance: Recent empirical literature and directions for future research. Journal of Economic Surveys, 29(4), pp.637-670.

Abedifar, P., Hasan, I., \& Tarazi, A. (2016). Finance-growth nexus and dual-banking systems: Relative importance of Islamic banks. Journal of Economic Behavior \& Organization, $132,198-215$.

Ahir, H., Bloom, N., \& Furceri, D. (2018). The world uncertainty index. Available at SSRN 3275033.

Agoraki, M.-E. K., Delis, M. D., \& Pasiouras, F. (2011). Regulations, competition and bank risk-taking in transition countries. Journal of Financial Stability, 7(1), 38-48.

Alandejani, M., Kutan, A.M. and Samargandi, N., 2017. Do Islamic banks fail more than conventional banks?. Journal of International Financial Markets, Institutions and Money, 50, pp.135-155.

Ashraf, B.N. and Shen, Y., 2019. Economic policy uncertainty and banks' loan pricing. Journal of Financial Stability, 44, p.100695.

Baker, S. R., \& Bloom, N. (2013). Does uncertainty reduce growth? Using disasters as natural experiments (No. w19475). National Bureau of Economic Research.

Baker, S.R., Bloom, N. and Davis, S.J., (2016). Measuring economic policy uncertainty. The quarterly journal of economics, 131(4), 1593-1636.

Barry, T. A., Lepetit, L., \& Tarazi, A. (2011). Ownership structure and risk in publicly held and privately owned banks. Journal of Banking \& Finance, 35(5), 1327-1340.

Beck, T., Demirgüç-Kunt, A., \& Merrouche, O. (2013a). Islamic vs. conventional banking: Business model, efficiency and stability. Journal of Banking \& Finance, 37, 433-447.

Beck, T., De Jonghe, O., \& Schepens, G. (2013b). Bank competition and stability: Cross-country heterogeneity. Journal of Financial Intermediation, 22(2), 218-244.

Berger, A. N., Miller, N. H., Petersen, M. A., Rajan, R. G., \& Stein, J. C. (2005). Does function follow organizational form? Evidence from the lending practices of large and small banks. Journal of Financial economics, 76(2), 237-269.

Berger, A. N., \& Black, L. K. (2011). Bank size, lending technologies, and small business finance. Journal of Banking \& Finance, 35(3), 724-735. 
Bilgin, M.H., Danisman, G.O., Demir, E. and Tarazi, A., (2020). Bank credit in uncertain times: Islamic vs. conventional banks. Finance Research Letters, forthcoming.

Bilgin, M. H., Gozgor, G., Lau, C. K. M., \& Sheng, X. (2018). The effects of uncertainty measures on the price of gold. International Review of Financial Analysis, 58, 1-7.

Bitar, M., \& Tarazi, A. (2019). Creditor rights and bank capital decisions: Conventional vs. Islamic banking. Journal of Corporate Finance, 55, 69-104.

Bordo, M.D., Duca, J.V. and Koch, C., 2016. Economic policy uncertainty and the credit channel: Aggregate and bank level US evidence over several decades. Journal of Financial Stability, 26, pp.90-106.

Bourkhis, K., \& Nabi, M. S. (2013). Islamic and conventional banks' soundness during the 2007-2008 financial crisis. Review of Financial economics, 22(2), 68-77.

Chi, Q. and Li, W., 2017. Economic policy uncertainty, credit risks and banks' lending decisions: Evidence from Chinese commercial banks. China journal of accounting research, 10(1), 33-50.

Čihák, M., \& Hesse, H. (2010). Islamic banks and financial stability: An empirical analysis. Journal of Financial Services Research, 38(2-3), 95-113. DeYoung, R., \& Roland, K. P. (2001). Product mix and earnings volatility at commercial banks: Evidence from a degree of total leverage model. Journal of Financial Intermediation, 10(1), 54-84.

Djankov, S., McLiesh, C., Shleifer, A., 2007. Private credit in 129 countries. Journal of FinancialEconomics,. 84, 299-329.

Doumpos, M., Hasan, I. and Pasiouras, F., 2017. Bank overall financial strength: Islamic versus conventional banks. Economic Modelling, 64, 513-523.

Goyeau, D., Tarazi, A., 1992. Evaluation du risque de de'faillance bancaire en Europe. Revue d'Economie Politique, 102 (2), 249-280.

Hasan, M., \& Dridi, J. (2010). The effect of the global crisis on Islamic and conventional banks: A comparative study. Journal of International Commerce, Economics and Policy, 2(2), 163-200.

He, Z. and Niu, J., 2018. The effect of economic policy uncertainty on bank valuations. Applied economics letters, 25(5), 345-347.

Houston, J. F., Lin, C., Lin, P., \& Ma, Y. (2010). Creditor rights, information sharing, and bank risk taking. Journal of financial Economics, 96(3), 485-512.

ICD-REFINITIV, 2020. Islamic Finance Development Report 2019 - Shifting

Dynamics. [online] Available at: https://icd-

ps.org/uploads/files/IFDI\%202019\%20DEF\%20digital1574605094_7214.pdf 
Jeon, B. N., Wu, J., Yao, Y., \& Chen, M. (2020). Economic uncertainty and bank risk: Evidence from emerging economies. Journal of International Financial Markets, Institutions and Money, 68, 101242. .

Jones, A. T., \& Sackley, W. H. (2016). An uncertain suggestion for gold-pricing models: the effect of economic policy uncertainty on gold prices. Journal of Economics and Finance, 40(2), 367-379.

Kabir, M.N., Worthington, A. and Gupta, R., 2015. Comparative credit risk in Islamic and conventional bank. Pacific-Basin Finance Journal, 34, pp.327-353.

Karadima, M. and Louri, H., 2020. Economic policy uncertainty and non-performing loans: The moderating role of bank concentration. Finance Research Letters, forthcoming..

Kleibergen, F. and Paap, R., 2006. Generalized reduced rank tests using the singular value decomposition. Journal of econometrics, 133(1), 97-126.

Lepetit, L., Nys, E., Rous, P., \& Tarazi, A. (2008a). Bank income structure and risk: An empirical analysis of European banks. Journal of banking \& finance, 32(8), 1452-1467.

Lepetit, L., Nys, E., Rous, P., \& Tarazi, A. (2008b). The expansion of services in European banking: Implications for loan pricing and interest margins. Journal of Banking \& Finance, 32(11), 2325-2335.

Meslier, C., Tacneng, R., \& Tarazi, A. (2014). Is bank income diversification beneficial? Evidence from an emerging economy. Journal of International Financial Markets, Institutions and Money, 31, 97-126.

Mobarek, A. and Kalonov, A., 2014. Comparative performance analysis between conventional and Islamic banks: empirical evidence from OIC countries. Applied Economics, 46(3), 253-270.

Mollah, S., \& Zaman, M. (2015). Shari'ah supervision, corporate governance and performance: Conventional vs. Islamic banks. Journal of Banking \& Finance, 58, 418-435.

Mollah, S., Hassan, M. K., Al Farooque, O., \& Mobarek, A. (2017). The governance, risk-taking, and performance of Islamic banks. Journal of financial services research, 51(2), 195-219.

Ng, J., Saffar, W. and Zhang, J.J., 2020. Policy uncertainty and loan loss provisions in the banking industry. Review of Accounting Studies, 25, 726-777.

Nguyen, C.P., Le, T.H. and Su, T.D., 2020. Economic policy uncertainty and credit growth: Evidence from a global sample. Research in International Business and Finance, 51, 101118. 
Pappas, V., Ongena, S., Izzeldin, M. and Fuertes, A.M., 2017. A survival analysis of Islamic and conventional banks. Journal of Financial Services Research, 51(2), 221-256.

Pew Research Center, (2009) Mapping the global Muslim population: a report on the size and distribution of the World's Muslim population, The Pew Forum on Religion \& Public Life, October 2009.

Phan, D.H.B., Iyke, B.N., Sharma, S.S., and Affandi, Y., 2020. Economic policy uncertainty and financial stability-Is there a relation? Economic Modelling, forthcoming

Rajhi, W. and Hassairi, S.A., 2013. Islamic banks and financial stability: a comparative empirical analysis between MENA and Southeast Asian countries. Région et développement, 37(1), pp.1-31.

Roodman, D. (2009), "How to do xtabond2: An introduction to difference and system GMM in Stata”, Stata Journal, 9(1), 86-136

Srairi, S., 2013. Ownership structure and risk-taking behaviour in conventional and Islamic banks: Evidence for MENA countries. Borsa Istanbul Review, 13(4), pp.115-127.

Sorwar, G., Pappas, V., Pereira, J. and Nurullah, M., 2016. To debt or not to debt: Are Islamic banks less risky than conventional banks?. Journal of Economic Behavior \& Organization, 132, pp.113-126.

Yudistra. D. (2004) Efficiency in Islamic banking: An empirical analysis of eighteen banks, Islamic Economic Studies 12, 1-19.

Weill, L. (2011) Do Islamic banks have greater market power? Comparative Economic Studies 53, 291-306. 


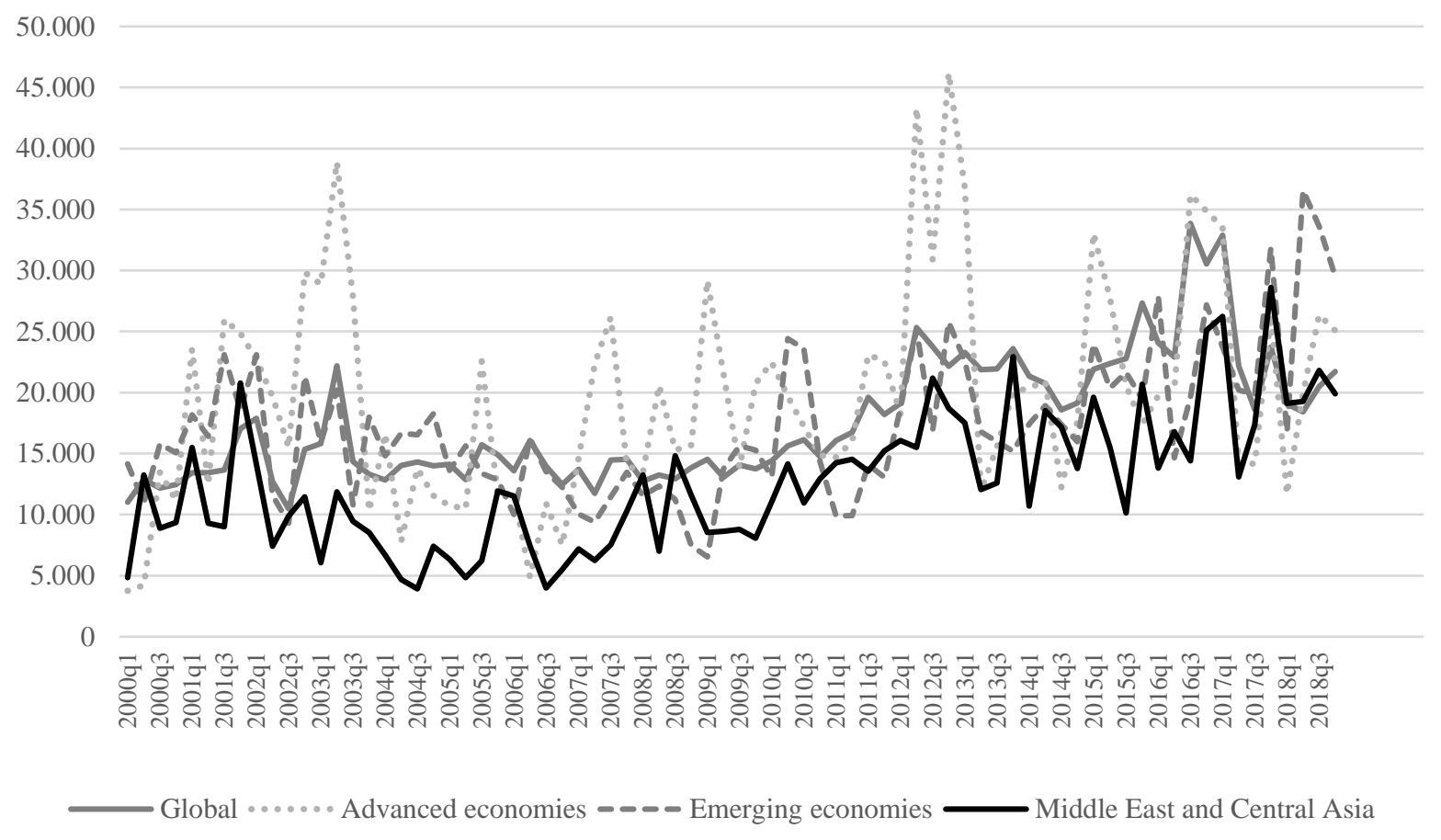

Figure 1. World Economic Uncertainty Index

Source: Ahir et al. (2018) 
Table 1:Variable Descriptions

\begin{tabular}{|c|c|c|}
\hline & Description & Data sources \\
\hline \multicolumn{3}{|l|}{ Dependent variables } \\
\hline DEFAULT RISK & $\begin{array}{l}\text { Negative of the natural logarithm of Z-score: }(-1) * \mathrm{Ln}[(\mathrm{ROA}+\mathrm{CAPITALIZATION}) / \mathrm{SD}(\mathrm{ROA})] \\
\text { where CAPITALIZATION stands for Equity to Total Assets and SD (ROA) is the standard } \\
\text { deviation of ROA, respectively. }\end{array}$ & Fitch Connect \\
\hline LEVERAGE RISK & $(-1) *$ Ln [CAPITALIZATION/ SD (ROA)] & Fitch Connect \\
\hline PORTFOLIO RISK & $(-1) * \mathrm{Ln}[\mathrm{ROA} / \mathrm{SD}(\mathrm{ROA})]$ & Fitch Connect \\
\hline \multicolumn{3}{|l|}{ Independent variables } \\
\hline WUI & Natural logarithm of average quarterly country-specific World Uncertainty index (WUI) & $\begin{array}{l}\text { Ahir et al. (2018) } \\
\text { (http://www.policyuncertainty.com/) }\end{array}$ \\
\hline WUI_V2 & $\begin{array}{l}\text { Natural logarithm of average quarterly country-specific WUI index calculated using the three- } \\
\text { quarter weighted moving average }\end{array}$ & $\begin{array}{l}\text { Ahir et al. (2018) } \\
\text { (http://www.policyuncertainty.com/) }\end{array}$ \\
\hline WUI_V3 & $\begin{array}{l}\text { Natural logarithm of average of first two quarters of country-specific World Uncertainty index } \\
\text { (WUI) }\end{array}$ & $\begin{array}{l}\text { Ahir et al. (2018) } \\
\text { (http://www.policyuncertainty.com/) }\end{array}$ \\
\hline ISLAMIC & A dummy variable that takes the value of 1 for Islamic banks; 0 otherwise & Fitch Connect \\
\hline SIZE & The natural logarithm of total assets & Fitch Connect \\
\hline GROWTH & Annual growth of total assets & Fitch Connect \\
\hline LOAN SHARE & Net loans/ Total assets & Fitch Connect \\
\hline NON-INTEREST INCOME & Non-interest income/Gross revenues & Fitch Connect \\
\hline LIQUIDITY & Liquid assets/ Total assets & Fitch Connect \\
\hline COST TO INCOME & Total costs/ Total income & Fitch Connect \\
\hline LISTED & A dummy variable that takes the value of 1 for publicly listed banks; 0 otherwise & Fitch Connect \\
\hline COMMISSION & The share of net fees and commissions in non-interest income & Fitch Connect \\
\hline TRADING & The share of net trading and derivatives in non-interest income & Fitch Connect \\
\hline \multicolumn{3}{|l|}{ Country Controls } \\
\hline GDP GROWTH & Real GDP growth rate & World Bank World Development Indicators \\
\hline INFLATION & The annual growth rate of the GDP implicit deflator & World Bank World Development Indicators \\
\hline OIL MINERAL & Oil and mineral rents as a share of GDP & World Bank World Development Indicators \\
\hline FOREIGN BANK ASSETS & $\begin{array}{l}\text { Percentage of the total banking assets that are held by foreign banks. A foreign bank is a bank } \\
\text { where } 50 \text { percent or more of its shares are owned by foreigners. }\end{array}$ & $\begin{array}{l}\text { World Bank Global Financial Development } \\
\text { Database }\end{array}$ \\
\hline CONCENTRATION & Assets of the three largest banks as a share of total commercial banking assets. & $\begin{array}{l}\text { World Bank Global Financial Development } \\
\text { Database }\end{array}$ \\
\hline MUSLIM SHARE & Percent of Muslim Population in the country. & Pew Research Center (2009) \\
\hline COMMON LAW & Equals 1 for the English common law legal origin countries; 0 otherwise & Djankov et al. (2007) \\
\hline CIVIL LAW & Equals 1 for the French civil law legal origin countries; 0 otherwise & Djankov et al. (2007) \\
\hline LEGAL SYSTEM & $\begin{array}{l}\text { Takes a value of } 0 \text { if the country does not have Shari'ah law in its legal system, and the value } 1 \text { for } \\
\text { countries that consider Shari'ah together with other legal system and the value } 2 \text { if the legal } \\
\text { system is based exclusively on Shari'ah law. }\end{array}$ & $\begin{array}{l}\text { CIA's World Fact Book } \\
\text { (https://www.cia.gov/library/publications/the- } \\
\text { world-factbook/fields/308.html) }\end{array}$ \\
\hline $\begin{array}{l}\text { IMPORTANCE OF } \\
\text { RELIGION }\end{array}$ & Share of population who consider religion to be very important. & World Values Surveys (WVS) \\
\hline
\end{tabular}


Table 2: Descriptive Statistics

\begin{tabular}{|c|c|c|c|c|c|c|c|c|c|c|c|}
\hline \multirow[b]{2}{*}{ Variable } & \multicolumn{6}{|c|}{ Full sample } & \multicolumn{2}{|c|}{ Islamic banks } & \multicolumn{2}{|c|}{ Conventional banks } & \multirow[b]{2}{*}{$\begin{array}{c}\text { Difference } \\
\text { t-test pvalue }\end{array}$} \\
\hline & $\mathbf{N}$ & Mean & Min & Max & SD & Median & $\mathbf{N}$ & Mean & $\mathbf{N}$ & Mean & \\
\hline DEFAULT RISK & 3615 & -3.99 & -8.01 & 0.13 & 1.13 & -3.93 & 516 & -4.00 & 3,099 & -3.99 & 0.903 \\
\hline LEVERAGE RISK & 3618 & -3.88 & -8.26 & 0.22 & 1.16 & -3.81 & 518 & -3.90 & 3,100 & -3.87 & 0.546 \\
\hline PORTFOLIO RISK & 3621 & -1.47 & -5.74 & 5.01 & 1.37 & -1.52 & 522 & -1.34 & 3,099 & -1.49 & 0.026 \\
\hline ISLAMIC & 5680 & 0.14 & 0 & 1 & 0.35 & 0 & & & & & \\
\hline WUI & 5328 & -2.15 & -4.05 & -0.29 & 0.87 & -2.20 & & & & & \\
\hline Within variation & & & & & 0.66 & & & & & & \\
\hline Between variation & & & & & 0.56 & & & & & & \\
\hline WUI_V2 & 5591 & -3.33 & -7.21 & -1.45 & 0.94 & -3.37 & & & & & \\
\hline WUI_V3 & 4469 & -1.99 & -3.76 & 0.35 & 0.84 & -2.20 & & & & & \\
\hline SIZE & 4507 & 7.67 & 3.02 & 11.79 & 1.90 & 7.63 & 650 & 7.70 & 3,857 & 7.67 & 0.664 \\
\hline GROWTH & 4183 & $18.65 \%$ & $0.25 \%$ & $143.23 \%$ & $21.73 \%$ & $12.69 \%$ & 604 & $18.92 \%$ & 3,579 & $18.61 \%$ & 0.747 \\
\hline LOAN SHARE & 4436 & $53.21 \%$ & $1.33 \%$ & $92.33 \%$ & $20.23 \%$ & $58.88 \%$ & 641 & $52.53 \%$ & 3,795 & $53.33 \%$ & 0.358 \\
\hline NON-INTEREST INCOME & 4476 & $32.94 \%$ & $1.35 \%$ & $122.61 \%$ & $24.11 \%$ & $27.63 \%$ & 642 & $38.19 \%$ & 3,834 & $32.06 \%$ & 0.000 \\
\hline COST TO INCOME & 4470 & $57.71 \%$ & $15.03 \%$ & $208.78 \%$ & $28.91 \%$ & $52.38 \%$ & 644 & $60.48 \%$ & 3,826 & $57.25 \%$ & 0.009 \\
\hline LIQUIDITY & 4504 & $21.60 \%$ & $1.11 \%$ & $87.31 \%$ & $16.65 \%$ & $17.24 \%$ & 647 & $21.21 \%$ & 3,857 & $21.67 \%$ & 0.518 \\
\hline LISTED & 5320 & 0.41 & 0 & 1 & 0.49 & & 800 & 0.34 & 4,520 & 0.42 & 0.000 \\
\hline COMMISSION & 3999 & $53.80 \%$ & $-46.51 \%$ & $180.86 \%$ & $33.25 \%$ & $55.71 \%$ & 567 & $52.31 \%$ & 3,432 & $54.05 \%$ & 0.247 \\
\hline TRADING & 2250 & $12.87 \%$ & $-159.30 \%$ & $153.82 \%$ & $35.27 \%$ & $9.32 \%$ & 267 & $11.03 \%$ & 1,983 & $13.11 \%$ & 0.365 \\
\hline \multicolumn{12}{|l|}{ Components of Z-score } \\
\hline ROA & 4218 & $1.74 \%$ & $0.03 \%$ & $12.03 \%$ & $1.85 \%$ & $1.27 \%$ & 610 & $1.61 \%$ & 3,608 & $1.77 \%$ & 0.047 \\
\hline CAPITALIZATION & 4503 & $16.60 \%$ & $2.91 \%$ & $89.12 \%$ & $15.53 \%$ & $11.79 \%$ & 646 & $17.60 \%$ & 3,857 & $16.44 \%$ & 0.077 \\
\hline \multicolumn{12}{|l|}{ Country Controls } \\
\hline GDP GROWTH & 5663 & $4.77 \%$ & $0.12 \%$ & $19.59 \%$ & $2.57 \%$ & $5.01 \%$ & & & & & \\
\hline INFLATION & 5663 & $7.64 \%$ & $0.02 \%$ & $47.17 \%$ & $6.76 \%$ & $5.87 \%$ & & & & & \\
\hline OIL MINERAL & 5112 & $8.43 \%$ & $0 \%$ & $61.23 \%$ & $13.17 \%$ & $2.79 \%$ & & & & & \\
\hline FOREIGN BANK ASSETS & 4734 & $20.37 \%$ & $0 \%$ & $94 \%$ & $17.51 \%$ & $21.00 \%$ & & & & & \\
\hline CONCENTRATION & 4788 & $51.85 \%$ & $26.45 \%$ & $100 \%$ & $17.98 \%$ & $43.56 \%$ & & & & & \\
\hline MUSLIM SHARE & 5680 & $84.87 \%$ & $14.90 \%$ & $99.50 \%$ & $17.15 \%$ & $89.60 \%$ & & & & & \\
\hline COMMON LAW & 5680 & 0.36 & 0 & 1 & 0.48 & 0 & & & & & \\
\hline CIVIL LAW & 5680 & 0.62 & 0 & 1 & 0.49 & 1 & & & & & \\
\hline LEGAL SYSTEM & 5680 & 0.71 & 0 & 2 & 0.56 & 1 & & & & & \\
\hline IMPORTANCE OF RELIGION & 4280 & $90.77 \%$ & $43.10 \%$ & $995.80 \%$ & $70.83 \%$ & $89.50 \%$ & & & & & \\
\hline
\end{tabular}


Table 3: The effect of WUI on bank stability: Islamic vs. Conventional banks

\begin{tabular}{|c|c|c|c|c|c|c|c|}
\hline & $\begin{array}{l}\text { (1) (DEFAULT } \\
\text { RISK) } \\
\end{array}$ & $\begin{array}{l}\text { (2) (LEVERAGE } \\
\text { RISK) }\end{array}$ & $\begin{array}{l}\text { (3) (PORTFOLIO } \\
\text { RISK) } \\
\end{array}$ & $\begin{array}{c}\text { (4) (DEFAULT } \\
\text { RISK) } \\
\end{array}$ & (5) (GMM) & (6) (WUI_V2) & (7) (WUI_V3) \\
\hline WUI & $\begin{array}{c}0.108 * * * \\
(0.03)\end{array}$ & $\begin{array}{l}0.112 * * * \\
(0.03)\end{array}$ & $\begin{array}{l}0.053^{*} \\
(0.03)\end{array}$ & $\begin{array}{c}0.092 * * * \\
(0.03)\end{array}$ & $\begin{array}{c}0.092 * * * \\
(0.03)\end{array}$ & $\begin{array}{l}0.108 * * * \\
(0.03)\end{array}$ & $\begin{array}{l}0.100 * * * \\
(0.03)\end{array}$ \\
\hline ISLAMIC & $\begin{array}{l}-0.496 * * * \\
(0.17)\end{array}$ & $\begin{array}{l}-0.546 * * * \\
(0.18)\end{array}$ & $\begin{array}{l}-0.192 \\
(0.24)\end{array}$ & $\begin{array}{l}-0.431 * * \\
(0.18)\end{array}$ & $\begin{array}{c}-0.831 * * \\
(0.41)\end{array}$ & $\begin{array}{l}-0.595 * * * \\
(0.23)\end{array}$ & $\begin{array}{l}-0.481 * * * \\
(0.17)\end{array}$ \\
\hline ISLAMIC*WUI & $\begin{array}{c}-0.161 * * \\
(0.06) \\
\end{array}$ & $\begin{array}{c}-0.172 * * * \\
(0.07) \\
\end{array}$ & $\begin{array}{l}-0.089 \\
(0.10)\end{array}$ & $\begin{array}{c}-0.149 * * \\
(0.07) \\
\end{array}$ & $\begin{array}{c}-0.295 * * \\
(0.15) \\
\end{array}$ & $\begin{array}{c}-0.138 * * \\
(0.06) \\
\end{array}$ & $\begin{array}{c}-0.163 * * * \\
(0.06) \\
\end{array}$ \\
\hline $\begin{array}{r}\text { WUI+ISLAMIC*WUI } \\
W U I+I S L A M I C * W U I \text {-p } \text {-value } \\
\end{array}$ & $\begin{array}{l}-0.053 \\
0.35 \\
\end{array}$ & $\begin{array}{l}-0.060 \\
0.31 \\
\end{array}$ & $\begin{array}{l}-0.036 \\
0.69 \\
\end{array}$ & $\begin{array}{l}-0.057 \\
0.36 \\
\end{array}$ & $\begin{array}{l}-0.204 \\
0.13 \\
\end{array}$ & $\begin{array}{l}-0.029 \\
0.60 \\
\end{array}$ & $\begin{array}{l}-0.063 \\
0.23 \\
\end{array}$ \\
\hline L.SIZE & $\begin{array}{l}-0.01 \\
(0.02)\end{array}$ & $\begin{array}{l}-0.006 \\
(0.02)\end{array}$ & $\begin{array}{c}-0.094 * * * \\
(0.02)\end{array}$ & $\begin{array}{l}-0.008 \\
(0.02)\end{array}$ & $\begin{array}{l}-0.043 \\
(0.05)\end{array}$ & $\begin{array}{l}-0.011 \\
(0.02)\end{array}$ & $\begin{array}{l}-0.016 \\
(0.02)\end{array}$ \\
\hline L.GROWTH & $\begin{array}{c}0.002^{* *} \\
(0.00)\end{array}$ & $\begin{array}{c}0.003 * * \\
(0.00)\end{array}$ & $\begin{array}{l}0.000 \\
(0.00)\end{array}$ & $\begin{array}{c}0.002 * \\
(0.00)\end{array}$ & $\begin{array}{c}0.005^{* * *} \\
(0.00)\end{array}$ & $\begin{array}{c}0.002 * * \\
(0.00)\end{array}$ & $\begin{array}{c}0.003 * * \\
(0.00)\end{array}$ \\
\hline L.LIQUIDITY & $\begin{array}{c}-0.003 \\
(0.00)\end{array}$ & $\begin{array}{l}-0.004 \\
(0.00)\end{array}$ & $\begin{array}{l}0.001 \\
(0.00)\end{array}$ & $\begin{array}{l}-0.002 \\
(0.00)\end{array}$ & $\begin{array}{l}0.003 \\
(0.01)\end{array}$ & $\begin{array}{c}-0.003 \\
(0.00)\end{array}$ & $\begin{array}{l}-0.004 \\
(0.00)\end{array}$ \\
\hline L.LOAN SHARE & $\begin{array}{c}-0.004^{*} \\
(0.00)\end{array}$ & $\begin{array}{c}-0.004 * \\
(0.00)\end{array}$ & $\begin{array}{l}-0.004 \\
(0.00)\end{array}$ & $\begin{array}{l}-0.002 \\
(0.00)\end{array}$ & $\begin{array}{l}-0.009 \\
(0.01)\end{array}$ & $\begin{array}{c}-0.004^{*} \\
(0.00)\end{array}$ & $\begin{array}{c}-0.005 * * \\
(0.00)\end{array}$ \\
\hline L.NON-INTEREST INCOME & $\begin{array}{c}0.005 * * * \\
(0.00)\end{array}$ & $\begin{array}{c}0.004 * * * \\
(0.00)\end{array}$ & $\begin{array}{c}0.005^{* * * *} \\
(0.00)\end{array}$ & $\begin{array}{c}0.005 * * * \\
(0.00)\end{array}$ & $\begin{array}{l}0.001 \\
(0.00)\end{array}$ & $\begin{array}{c}0.004 * * * \\
(0.00)\end{array}$ & $\begin{array}{c}0.005^{* * *} * \\
(0.00)\end{array}$ \\
\hline L.COST TO INCOME & $\begin{array}{c}0.004 * * * \\
(0.00)\end{array}$ & $\begin{array}{c}0.003 * * * \\
(0.00)\end{array}$ & $\begin{array}{c}0.009 * * * \\
(0.00)\end{array}$ & $\begin{array}{c}0.004 * * * \\
(0.00)\end{array}$ & & $\begin{array}{c}0.004 * * * \\
(0.00)\end{array}$ & $\begin{array}{c}0.003 * * * \\
(0.00)\end{array}$ \\
\hline L.GDP GROWTH & $\begin{array}{c}0.01 \\
(0.01)\end{array}$ & $\begin{array}{l}0.011 \\
(0.01)\end{array}$ & $\begin{array}{l}0.007 \\
(0.01)\end{array}$ & $\begin{array}{l}0.015 \\
(0.01)\end{array}$ & $\begin{array}{l}0.001 \\
(0.01)\end{array}$ & $\begin{array}{c}0.01 \\
(0.01)\end{array}$ & $\begin{array}{c}0.01 \\
(0.01)\end{array}$ \\
\hline L.INFLATION & $\begin{array}{c}0.008 * * \\
(0.00)\end{array}$ & $\begin{array}{c}0.009 * * \\
(0.00)\end{array}$ & $\begin{array}{l}0.001 \\
(0.00)\end{array}$ & $\begin{array}{c}0.015 * * * \\
-0.004\end{array}$ & $\begin{array}{c}0.008 * * \\
(0.00)\end{array}$ & $\begin{array}{c}0.009 * * \\
(0.00)\end{array}$ & $\begin{array}{c}0.008 * * \\
(0.00)\end{array}$ \\
\hline L.OIL MINERAL & $\begin{array}{c}-0.058 * * * \\
(0.02)\end{array}$ & $\begin{array}{c}-0.057 * * * \\
(0.02)\end{array}$ & $\begin{array}{c}-0.046^{* *} \\
(0.02)\end{array}$ & $\begin{array}{c}-0.063 * * * \\
(0.02)\end{array}$ & $\begin{array}{c}-0.050 * * * \\
(0.02)\end{array}$ & $\begin{array}{c}-0.055^{* * *} * \\
(0.02)\end{array}$ & $\begin{array}{c}-0.070 * * * \\
(0.02)\end{array}$ \\
\hline L.FOREIGN BANK ASSETS & & & & $\begin{array}{c}0.006^{* *} \\
(0.00)\end{array}$ & & & \\
\hline L.CONCENTRATION & & & & $\begin{array}{l}0.000 \\
(0.00)\end{array}$ & & & \\
\hline L.DEFAULT RISK & & & & & $\begin{array}{c}0.305 * * * \\
(0.05)\end{array}$ & & \\
\hline CONSTANT & $\begin{array}{c}-3.778 * * * \\
(0.29) \\
\end{array}$ & $\begin{array}{c}-3.657 * * * \\
(0.30) \\
\end{array}$ & $\begin{array}{c}-1.072 * * * \\
(0.32) \\
\end{array}$ & $\begin{array}{c}-4.206^{* * * *} \\
(0.39) \\
\end{array}$ & $\begin{array}{c}-1.859 * * * \\
(0.72) \\
\end{array}$ & $\begin{array}{c}-3.669 * * * \\
(0.30)\end{array}$ & $\begin{array}{c}-3.665 * * * \\
(0.29) \\
\end{array}$ \\
\hline $\mathrm{R} 2$ & 0.1322 & 0.1257 & 0.2554 & 0.1512 & & 0.1347 & 0.1479 \\
\hline
\end{tabular}


Observations

Number of Banks

3112

506

Number_of instruments

Year FE

Wald Chi2

YES

$80.35 * *$

AR1

AR2

Hansen's J stat
3115

3118

507

YES

YES

$79.62 * *$

126.22***

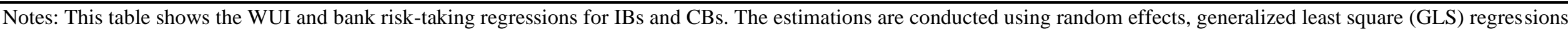
except Column 5. DEFAULT RISK is used as dependent variables in all columns except Columns $2 \& 3$. Columns 2 and 3 use LEVERAGE RISK and PORTFOLIO RISK as

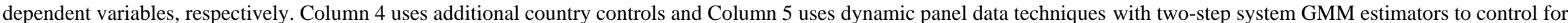
endogeneity. Columns 6 and 7 use alternative WUI measures: WUI_V2 and WUI_V3, respectively. Standard errors are clustered at the bank level and reported in parentheses. $* \mathrm{p}<0.10, * * \mathrm{p}<0.05, * * * \mathrm{p}<0.010$ 
Table 4: The effect of WUI on bank stability: subsample estimations

\begin{tabular}{|c|c|c|c|c|}
\hline & $\begin{array}{c}\text { (1) (Islamic) } \\
\text { (Random effects GLS) }\end{array}$ & $\begin{array}{c}\text { (2) (Conventional) } \\
\text { (Random effects GLS) }\end{array}$ & $\begin{array}{l}\text { (3) (Islamic) } \\
\text { (IV 2SLS) }\end{array}$ & $\begin{array}{l}\text { (4) (Conventional) } \\
\text { (IV 2SLS) }\end{array}$ \\
\hline \multirow[t]{2}{*}{ WUI } & -0.085 & $0.087 * * *$ & -0.047 & $0.114 * *$ \\
\hline & $(0.06)$ & $(0.03)$ & $(0.18)$ & $(0.07)$ \\
\hline \multirow[t]{2}{*}{ L.SIZE } & -0.029 & -0.033 & 0.013 & 0.131 \\
\hline & $(0.06)$ & $(0.02)$ & $(0.21)$ & $(0.08)$ \\
\hline \multirow[t]{2}{*}{ L.GROWTH } & 0.000 & $0.003 * * *$ & -0.001 & 0.002 \\
\hline & $(0.00)$ & $(0.00)$ & $(0.00)$ & $(0.00)$ \\
\hline \multirow[t]{2}{*}{ L.LIQUIDITY } & 0.002 & -0.004 & $0.013^{*}$ & -0.005 \\
\hline & $(0.01)$ & $(0.00)$ & $(0.01)$ & $(0.00)$ \\
\hline \multirow[t]{2}{*}{ L.LOAN SHARE } & 0.001 & -0.001 & 0.004 & -0.003 \\
\hline & $(0.01)$ & $(0.00)$ & $(0.01)$ & $(0.00)$ \\
\hline \multirow[t]{2}{*}{ L.NON-INTEREST INCOME } & $0.006^{* *}$ & $0.005 * * *$ & $0.006^{*}$ & 0.002 \\
\hline & $(0.00)$ & $(0.00)$ & $(0.00)$ & $(0.00)$ \\
\hline \multirow[t]{2}{*}{ L.COST TO INCOME } & 0.001 & $0.004 * * *$ & 0.003 & $0.003 * *$ \\
\hline & $(0.00)$ & $(0.00)$ & $(0.00)$ & $(0.00)$ \\
\hline \multirow{2}{*}{ L.GDP GROWTH } & 0.02 & 0.005 & 0.007 & $0.023 * *$ \\
\hline & $(0.02)$ & $(0.01)$ & $(0.02)$ & $(0.01)$ \\
\hline \multirow[t]{2}{*}{ L.INFLATION } & $0.014 *$ & 0.005 & $0.014 *$ & -0.004 \\
\hline & $(0.01)$ & $(0.00)$ & $(0.01)$ & $(0.01)$ \\
\hline \multirow[t]{2}{*}{ L.OIL MINERAL } & -0.005 & -0.004 & 0.013 & -0.003 \\
\hline & $(0.01)$ & $(0.00)$ & $(0.01)$ & $(0.01)$ \\
\hline \multirow[t]{2}{*}{ CONSTANT } & $-4.678 * * *$ & $-3.857 * * *$ & & \\
\hline & $(0.66)$ & $(0.30)$ & & \\
\hline $\mathrm{R} 2$ & 0.0583 & 0.124 & 0.0491 & 0.0566 \\
\hline Observations & 476 & 2932 & 398 & 2535 \\
\hline Number of Banks & 81 & 474 & 73 & 447 \\
\hline Year FE & YES & YES & YES & YES \\
\hline Wald Chi2 & $34.28 * *$ & $53.39 * * *$ & & \\
\hline Hansen J stat. & & & 0.891 & 6.561 \\
\hline Hansen J stat. p-value & & & 0.9259 & 0.161 \\
\hline Kleibergen-Paap Wald F test & & & $24.597 * * *$ & $191.65 * * *$ \\
\hline
\end{tabular}

Notes: This table shows the WUI and DEFAULT RISK regressions by splitting the sample into Islamic vs Conventional banks. While the estimations in Columns

$1 \& 2$ are conducted using random effects, generalized least square (GLS) regressions; Columns $3 \& 4$ use instrumental variable (IV) approach with two-Stage Least Squares regression (2SLS). Standard errors are clustered at the bank level and reported in parentheses. $* \mathrm{p}<0.10, * * \mathrm{p}<0.05, * * * \mathrm{p}<0.010$ 
Table 5: The effect of WUI on bank stability: the influence of religiosity

\begin{tabular}{|c|c|c|c|c|c|c|}
\hline & $\begin{array}{l}\text { (1) (MUSLIM } \\
\text { SHARE +90) }\end{array}$ & $\begin{array}{c}\text { (2) } \\
\text { (MUSLIM } \\
\text { SHARE -90) }\end{array}$ & $\begin{array}{c}\text { (3) (IMPORTANCE } \\
\text { OF RELIGION: } \\
\text { High) }\end{array}$ & $\begin{array}{l}\text { (4) (IMPORTANCE } \\
\text { OF RELIGION: } \\
\text { Low) }\end{array}$ & $\begin{array}{l}\text { (5) (Shari'ah } \\
\text { law) }\end{array}$ & $\begin{array}{c}\text { (6) (No } \\
\text { Shari'ah law) }\end{array}$ \\
\hline WUI & $\begin{array}{l}0.143 * * * \\
(0.04)\end{array}$ & $\begin{array}{l}0.024 \\
(0.03)\end{array}$ & $\begin{array}{c}0.081 * * \\
(0.03)\end{array}$ & $\begin{array}{l}0.153 * * * \\
(0.04)\end{array}$ & $\begin{array}{l}0.132 * * * \\
(0.04)\end{array}$ & $\begin{array}{l}0.067 * \\
(0.04)\end{array}$ \\
\hline ISLAMIC & $\begin{array}{c}-0.555^{* * *} \\
(0.28)\end{array}$ & $\begin{array}{l}-0.251 \\
(0.21)\end{array}$ & $\begin{array}{l}-0.651 * * * \\
(0.24)\end{array}$ & $\begin{array}{l}-0.242 \\
(0.22)\end{array}$ & $\begin{array}{l}-0.581 * * * \\
(0.17)\end{array}$ & $\begin{array}{l}-0.092 \\
(0.41)\end{array}$ \\
\hline ISLAMIC*WUI & $\begin{array}{c}-0.187^{*} \\
(0.11)\end{array}$ & $\begin{array}{l}-0.106 \\
(0.08)\end{array}$ & $\begin{array}{c}-0.236 * * * \\
(0.09)\end{array}$ & $\begin{array}{l}-0.096 \\
(0.08)\end{array}$ & $\begin{array}{c}-0.214 * * * \\
(0.06)\end{array}$ & $\begin{array}{l}-0.077 \\
(0.17)\end{array}$ \\
\hline $\begin{array}{r}W U I+I S L A M I C * W U I \\
W U I+I S L A M I C * W U I-p \text {-value }\end{array}$ & $\begin{array}{c}-0.04 \\
0.66\end{array}$ & $\begin{array}{l}-0.08 \\
0.24\end{array}$ & $\begin{array}{c}-0.16 \\
0.07\end{array}$ & $\begin{array}{l}0.06 \\
0.44\end{array}$ & $\begin{array}{c}-0.08 \\
0.11\end{array}$ & $\begin{array}{l}-0.01 \\
0.95\end{array}$ \\
\hline L.SIZE & $\begin{array}{l}-0.001 \\
(0.03)\end{array}$ & $\begin{array}{c}-0.066^{* *} \\
(0.03)\end{array}$ & $\begin{array}{l}0.006 \\
(0.03)\end{array}$ & $\begin{array}{c}-0.046^{*} \\
(0.03)\end{array}$ & $\begin{array}{c}-0.069 * * \\
(0.03)\end{array}$ & $\begin{array}{l}0.015 \\
(0.03)\end{array}$ \\
\hline L.GROWTH & $\begin{array}{l}0.004 * * * \\
(0.00)\end{array}$ & $\begin{array}{l}0.002 \\
(0.00)\end{array}$ & $\begin{array}{l}0.002 \\
(0.00)\end{array}$ & $\begin{array}{c}0.005 * * * \\
(0.00)\end{array}$ & $\begin{array}{l}0.003 * \\
(0.00)\end{array}$ & $\begin{array}{c}0.003 * * \\
(0.00)\end{array}$ \\
\hline L.LIQUIDITY & $\begin{array}{c}-0.004 \\
(0.00)\end{array}$ & $\begin{array}{l}-0.001 \\
(0.00)\end{array}$ & $\begin{array}{l}-0.001 \\
(0.00)\end{array}$ & $\begin{array}{c}-0.007 * \\
(0.00)\end{array}$ & $\begin{array}{c}-0.006^{* * *} \\
(0.00)\end{array}$ & $\begin{array}{l}0.002 \\
(0.01)\end{array}$ \\
\hline L.LOAN SHARE & $\begin{array}{c}-0.006^{* * *} \\
(0.00)\end{array}$ & $\begin{array}{l}0.004 \\
(0.00)\end{array}$ & $\begin{array}{l}-0.005 \\
(0.00)\end{array}$ & $\begin{array}{c}0 \\
(0.00)\end{array}$ & $\begin{array}{l}-0.001 \\
(0.00)\end{array}$ & $\begin{array}{l}-0.002 \\
(0.00)\end{array}$ \\
\hline L.NON-INTEREST INCOME & $\begin{array}{c}0.004 * * \\
(0.00)\end{array}$ & $\begin{array}{c}0.005^{* *} \\
(0.00)\end{array}$ & $\begin{array}{c}0.004 * * \\
(0.00)\end{array}$ & $\begin{array}{c}0.005^{* *} \\
(0.00)\end{array}$ & $\begin{array}{c}0.005 * * * \\
(0.00)\end{array}$ & $\begin{array}{l}0.003 \\
(0.00)\end{array}$ \\
\hline L.COST TO INCOME & $\begin{array}{c}0.005 * * * \\
(0.00)\end{array}$ & $\begin{array}{l}0.002 \\
(0.00)\end{array}$ & $\begin{array}{c}0.004 * * * \\
(0.00)\end{array}$ & $\begin{array}{c}0.003^{* *} \\
(0.00)\end{array}$ & $\begin{array}{c}0.003^{* *} \\
(0.00)\end{array}$ & $\begin{array}{c}0.005 * * * \\
(0.00)\end{array}$ \\
\hline L.GDP GROWTH & $\begin{array}{l}0.022^{*} \\
(0.01)\end{array}$ & $\begin{array}{l}-0.013 \\
(0.01)\end{array}$ & $\begin{array}{l}0.007 \\
(0.01)\end{array}$ & $\begin{array}{l}0.005 \\
(0.01)\end{array}$ & $\begin{array}{l}0.013 \\
(0.01)\end{array}$ & $\begin{array}{l}0.005 \\
(0.02)\end{array}$ \\
\hline L.INFLATION & $\begin{array}{c}0 \\
(0.01)\end{array}$ & $\begin{array}{c}0.016^{* * * *} \\
(0.01)\end{array}$ & $\begin{array}{c}0.014 * * * \\
(0.00)\end{array}$ & $\begin{array}{c}-0.010 * \\
(0.01)\end{array}$ & $\begin{array}{l}0.007 * \\
(0.00)\end{array}$ & $\begin{array}{l}0.004 \\
(0.01)\end{array}$ \\
\hline L.OIL MINERAL & $\begin{array}{l}-0.004 \\
(0.00)\end{array}$ & $\begin{array}{l}-0.006 \\
(0.01)\end{array}$ & $\begin{array}{c}-0.014 * * * \\
(0.01)\end{array}$ & $\begin{array}{l}0.007 * \\
(0.00)\end{array}$ & $\begin{array}{l}-0.002 \\
(0.00)\end{array}$ & $\begin{array}{l}-0.008 \\
(0.01)\end{array}$ \\
\hline CONSTANT & $\begin{array}{c}-3.657 * * * \\
(0.37)\end{array}$ & $\begin{array}{c}-4.071 * * * \\
(0.37)\end{array}$ & $\begin{array}{c}-3.871 * * * \\
(0.37)\end{array}$ & $\begin{array}{c}-3.746 * * * \\
(0.38)\end{array}$ & $\begin{array}{c}-3.469 * * * \\
(0.34)\end{array}$ & $\begin{array}{c}-4.290 * * * \\
(0.48)\end{array}$ \\
\hline $\mathrm{R} 2$ & 0.1653 & 0.1205 & 0.1433 & 0.1783 & 0.1281 & 0.1105 \\
\hline Wald Chi2 & $51.45 * * *$ & $43.97 * * *$ & $64.04 * * *$ & $41.63 * * *$ & $65.02 * * *$ & $37.21 * * *$ \\
\hline Observations & 1405 & 2003 & 2083 & 1325 & 2153 & 1420 \\
\hline Number of Banks & 231 & 324 & 320 & 235 & 365 & 219 \\
\hline Year FE & YES & YES & YES & YES & YES & YES \\
\hline
\end{tabular}


Table 6: The effect of WUI on bank stability : influence of the institutional environment

\begin{tabular}{|c|c|c|c|c|c|c|}
\hline & $\begin{array}{c}(1) \\
\text { (COMMON LAW) }\end{array}$ & $\begin{array}{c}(2) \\
\text { (CIVIL LAW) }\end{array}$ & $\begin{array}{c}(3) \\
(\mathbf{G C C})\end{array}$ & $\begin{array}{c}(4) \\
\text { (Non-GCC) }\end{array}$ & (5) (Rich) & (6) (Poor) \\
\hline WUI & $\begin{array}{c}0.105^{* *} \\
(0.05)\end{array}$ & $\begin{array}{c}0.068^{* *} \\
(0.03)\end{array}$ & $\begin{array}{c}0.185^{* * *} \\
(0.09)\end{array}$ & $\begin{array}{c}0.077 * * * * \\
(0.03)\end{array}$ & $\begin{array}{l}0.149 * * * \\
(0.03)\end{array}$ & $\begin{array}{l}0.029 \\
(0.04)\end{array}$ \\
\hline ISLAMIC & $\begin{array}{l}-0.529 * * \\
(0.23)\end{array}$ & $\begin{array}{l}-0.223 \\
(0.26)\end{array}$ & $\begin{array}{l}-0.235 \\
(0.39)\end{array}$ & $\begin{array}{c}-0.407 * * \\
(0.18)\end{array}$ & $\begin{array}{c}-0.357^{*} \\
(0.21)\end{array}$ & $\begin{array}{c}-0.572 * * \\
(0.26)\end{array}$ \\
\hline ISLAMIC*WUI & $\begin{array}{c}-0.198 * * \\
(0.08) \\
\end{array}$ & $\begin{array}{l}-0.042 \\
(0.09) \\
\end{array}$ & $\begin{array}{l}-0.121 \\
(0.12) \\
\end{array}$ & $\begin{array}{c}-0.141^{* *} \\
(0.07) \\
\end{array}$ & $\begin{array}{c}-0.136^{*} \\
(0.07) \\
\end{array}$ & $\begin{array}{c}-0.179^{*} \\
(0.10) \\
\end{array}$ \\
\hline $\begin{array}{r}\text { WUI+ISLAMIC*WUI } \\
\text { WUI+ISLAMIC*WUI -pvalue }\end{array}$ & $\begin{array}{c}-0.09 \\
0.16\end{array}$ & $\begin{array}{l}0.03 \\
0.77\end{array}$ & $\begin{array}{l}0.06 \\
0.52\end{array}$ & $\begin{array}{c}-0.06 \\
0.34\end{array}$ & $\begin{array}{l}0.01 \\
0.84\end{array}$ & $\begin{array}{c}-0.15 \\
0.12\end{array}$ \\
\hline L.GROWTH & $\begin{array}{l}0.002 \\
(0.00)\end{array}$ & $\begin{array}{c}0.003 * * * \\
(0.00)\end{array}$ & $\begin{array}{l}0.001 \\
(0.01)\end{array}$ & $\begin{array}{c}0.003 * * * \\
(0.00)\end{array}$ & $\begin{array}{c}0.003^{* *} \\
(0.00)\end{array}$ & $\begin{array}{c}0.003^{* *} \\
(0.00)\end{array}$ \\
\hline L.LIQUIDITY & $\begin{array}{c}-0.012 * * * \\
(0.00)\end{array}$ & $\begin{array}{l}0.001 \\
(0.00)\end{array}$ & $\begin{array}{l}-0.001 \\
(0.01)\end{array}$ & $\begin{array}{l}-0.003 \\
(0.00)\end{array}$ & $\begin{array}{l}-0.002 \\
(0.00)\end{array}$ & $\begin{array}{l}-0.002 \\
(0.00)\end{array}$ \\
\hline L.LOAN SHARE & $\begin{array}{c}-0.004 \\
(0.00)\end{array}$ & $\begin{array}{l}0.001 \\
(0.00)\end{array}$ & $\begin{array}{r}-0.005 \\
(0.01)\end{array}$ & $\begin{array}{l}0.000 \\
(0.00)\end{array}$ & $\begin{array}{l}0.004 \\
(0.00)\end{array}$ & $\begin{array}{l}-0.004 \\
(0.00)\end{array}$ \\
\hline L.NON-INTEREST INCOME & $\begin{array}{l}0.003 \\
(0.00)\end{array}$ & $\begin{array}{c}0.006 * * * \\
(0.00)\end{array}$ & $\begin{array}{l}0.006 \\
(0.01)\end{array}$ & $\begin{array}{c}0.005^{* * * *} \\
(0.00)\end{array}$ & $\begin{array}{c}0.005^{* * *} \\
(0.00)\end{array}$ & $\begin{array}{c}0.005^{* *} \\
(0.00)\end{array}$ \\
\hline L.COST TO INCOME & $\begin{array}{l}0.001 \\
(0.00)\end{array}$ & $\begin{array}{c}0.004 * * * \\
(0.00)\end{array}$ & $\begin{array}{c}0.003^{*} \\
(0.00)\end{array}$ & $\begin{array}{c}0.004 * * * \\
(0.00)\end{array}$ & $\begin{array}{c}0.004 * * * \\
(0.00)\end{array}$ & $\begin{array}{c}0.005^{* * * *} \\
(0.00)\end{array}$ \\
\hline L.INFLATION & $\begin{array}{l}0.008 \\
(0.01)\end{array}$ & $\begin{array}{l}0.003 \\
(0.00)\end{array}$ & $\begin{array}{l}0.005 \\
(0.01)\end{array}$ & $\begin{array}{c}0.009^{* *} \\
(0.01)\end{array}$ & $\begin{array}{r}-0.001 \\
(0.01)\end{array}$ & $\begin{array}{c}0.018^{* * *} \\
(0.01)\end{array}$ \\
\hline L.OIL MINERAL & $\begin{array}{c}0.00 \\
-0.004\end{array}$ & $\begin{array}{l}(0.00) \\
-0.004\end{array}$ & $\begin{array}{c}0.00 \\
-0.006\end{array}$ & $\begin{array}{l}(0.00) \\
-0.005\end{array}$ & $\begin{array}{l}0.003 \\
(0.00)\end{array}$ & $\begin{array}{c}-0.017 * \\
(0.01)\end{array}$ \\
\hline CONSTANT & $\begin{array}{c}-2.976 * * * \\
(0.50) \\
\end{array}$ & $\begin{array}{c}-4.294 * * * \\
(0.32) \\
\end{array}$ & $\begin{array}{c}-3.928 * * * \\
(1.07) \\
\end{array}$ & $\begin{array}{c}-4.021 * * * * \\
(0.29) \\
\end{array}$ & $\begin{array}{c}-3.757 * * * \\
(0.37) \\
\end{array}$ & $\begin{array}{c}-4.359 * * * * \\
(0.41) \\
\end{array}$ \\
\hline R2 & 0.1536 & 0.102 & 0.155 & 0.1113 & 0.1109 & 0.1089 \\
\hline Wald Chi2 & $59 * * *$ & $45.77 * * *$ & $27.25 * * *$ & $46.46 * * *$ & $54.42 * * *$ & $50.91 * * *$ \\
\hline Observations & 1053 & 2302 & 495 & 2913 & 1719 & 1689 \\
\hline Number of Banks & 194 & 346 & 66 & 489 & 372 & 312 \\
\hline Year FE & YES & YES & YES & YES & YES & YES \\
\hline
\end{tabular}

Notes: This table shows the WUI and DEFAULT RISK regressions and considers the influence of the institutional environment by splitting the sample into country characteristics. The estimations are conducted using random effects, generalized least square (GLS) regressions. Columns 1 and 2 show the results for COMMON LAW and CIVIL LAW countries, respectively. Columns 3 and 4 incorporate results for GCC and non-GCC countries. Columns $5 \& 6$ show the results for rich (GDP per capita>median) and poor (GDP per capita<median) countries. Standard errors are clustered at the bank level and reported in parentheses. $* \mathrm{p}<0.10, * * \mathrm{p}<0.05, * * * \mathrm{p}<0.010$ 
Table 7: Cross-sectional analyses on bank heterogeneity

\begin{tabular}{|c|c|c|c|c|c|c|c|c|}
\hline & $\begin{array}{c}\text { (1) (High NON-INTEREST } \\
\text { INCOME) }\end{array}$ & $\begin{array}{l}\text { (2) (Low } \\
\text { NON- } \\
\text { INTEREST } \\
\text { INCOME) }\end{array}$ & $\begin{array}{l}\text { (3) High NON- } \\
\text { INTEREST } \\
\text { INCOME- } \\
\text { Trading } \\
\text { Oriented } \\
\end{array}$ & $\begin{array}{c}\text { (4) High NON- } \\
\text { INTEREST } \\
\text { INCOME- } \\
\text { Commission and Fee } \\
\text { Oriented } \\
\end{array}$ & $\begin{array}{c}(\mathbf{5}) \\
(\text { Large })\end{array}$ & $\begin{array}{c}(6) \\
\text { (Small) }\end{array}$ & $\begin{array}{c}\text { (7) } \\
\text { (LISTED) }\end{array}$ & $\begin{array}{l}\text { (8) (Non- } \\
\text { LISTED) }\end{array}$ \\
\hline WUI & $\begin{array}{c}0.171 * * * \\
(0.04)\end{array}$ & $\begin{array}{l}0.036 \\
(0.03)\end{array}$ & $\begin{array}{c}0.175^{* * * *} \\
(0.05)\end{array}$ & $\begin{array}{c}0.195 * * * \\
(0.06)\end{array}$ & $\begin{array}{c}0.141 * * * \\
(0.03)\end{array}$ & $\begin{array}{l}0.076^{*} \\
(0.04)\end{array}$ & $\begin{array}{c}0.163 * * * \\
(0.04)\end{array}$ & $\begin{array}{l}0.055 \\
(0.04)\end{array}$ \\
\hline ISLAMIC & $\begin{array}{c}-0.730 * * * \\
(0.25)\end{array}$ & $\begin{array}{l}-0.264 \\
(0.19)\end{array}$ & $\begin{array}{c}-0.728 * * \\
(0.29)\end{array}$ & $\begin{array}{c}-0.917 * * \\
(0.37)\end{array}$ & $\begin{array}{l}-0.269 \\
(0.22)\end{array}$ & $\begin{array}{c}-0.849 * * * \\
(0.24)\end{array}$ & $\begin{array}{c}-0.508 * * \\
(0.26)\end{array}$ & $\begin{array}{c}-0.522 * * \\
(0.22)\end{array}$ \\
\hline ISLAMIC*WUI & $\begin{array}{c}-0.278 * * * * \\
(0.09)\end{array}$ & $\begin{array}{l}-0.046 \\
(0.08)\end{array}$ & $\begin{array}{c}-0.282 * * \\
(0.11)\end{array}$ & $\begin{array}{c}-0.427 * * * \\
(0.14)\end{array}$ & $\begin{array}{l}-0.076 \\
(0.08)\end{array}$ & $\begin{array}{c}-0.297 * * * \\
(0.10)\end{array}$ & $\begin{array}{c}-0.207 * * \\
(0.10) \\
\end{array}$ & $\begin{array}{l}-0.123 \\
(0.08)\end{array}$ \\
\hline $\begin{array}{r}\text { WUI+ISLAMIC*WUI } \\
\text { WUI+ISLAMIC*WUI -pvalue }\end{array}$ & $\begin{array}{c}-0.107 \\
0.18\end{array}$ & $\begin{array}{c}-0.01 \\
0.90 \\
\end{array}$ & $\begin{array}{c}-0.107 \\
0.29\end{array}$ & $\begin{array}{c}-0.232 \\
0.07\end{array}$ & $\begin{array}{l}0.07 \\
0.35\end{array}$ & $\begin{array}{c}-0.221 \\
0.01 \\
\end{array}$ & $\begin{array}{c}-0.044 \\
0.62\end{array}$ & $\begin{array}{c}-0.068 \\
0.35\end{array}$ \\
\hline L.SIZE & $\begin{array}{c}-0.052 * \\
(0.03)\end{array}$ & $\begin{array}{l}0.008 \\
(0.03)\end{array}$ & $\begin{array}{l}-0.034 \\
(0.03)\end{array}$ & $\begin{array}{c}-0.098 * * * \\
(0.04)\end{array}$ & & & $\begin{array}{l}-0.04 \\
(0.03)\end{array}$ & $\begin{array}{c}0.05 \\
(0.03)\end{array}$ \\
\hline L.GROWTH & $\begin{array}{l}0.001 \\
(0.00)\end{array}$ & $\begin{array}{c}0.004 * * * \\
(0.00)\end{array}$ & $\begin{array}{l}0.001 \\
(0.00)\end{array}$ & $\begin{array}{c}0 \\
(0.00)\end{array}$ & $\begin{array}{c}0.006 * * * \\
(0.00)\end{array}$ & $\begin{array}{l}0.002 \\
(0.00)\end{array}$ & $\begin{array}{l}0.003^{*} \\
(0.00)\end{array}$ & $\begin{array}{l}0.002 \\
(0.00)\end{array}$ \\
\hline L.LIQUIDITY & $\begin{array}{l}-0.003 \\
(0.00)\end{array}$ & $\begin{array}{l}-0.004 \\
(0.00)\end{array}$ & $\begin{array}{c}0 \\
(0.00)\end{array}$ & $\begin{array}{l}0.002 \\
(0.01)\end{array}$ & $\begin{array}{l}-0.001 \\
(0.00)\end{array}$ & $\begin{array}{l}-0.004 \\
(0.00)\end{array}$ & $\begin{array}{l}-0.005 \\
(0.01)\end{array}$ & $\begin{array}{l}-0.003 \\
(0.00)\end{array}$ \\
\hline L.LOAN SHARE & $\begin{array}{l}-0.003 \\
(0.00)\end{array}$ & $\begin{array}{c}-0.006 * * \\
(0.00)\end{array}$ & $\begin{array}{l}-0.001 \\
(0.00)\end{array}$ & $\begin{array}{l}-0.001 \\
(0.00)\end{array}$ & $\begin{array}{c}-0.007 * * \\
(0.00)\end{array}$ & $\begin{array}{l}-0.005 \\
(0.00)\end{array}$ & $\begin{array}{l}-0.005 \\
(0.00)\end{array}$ & $\begin{array}{l}-0.004 \\
(0.00)\end{array}$ \\
\hline L.NON-INTEREST INCOME & & & & & $\begin{array}{l}0.004 \\
(0.00)\end{array}$ & $\begin{array}{c}0.005^{* *} \\
(0.00)\end{array}$ & $\begin{array}{c}0.006 * * * \\
(0.00)\end{array}$ & $\begin{array}{l}0.003 \\
(0.00)\end{array}$ \\
\hline L.COST TO INCOME & $\begin{array}{c}0.002^{*} \\
(0.00)\end{array}$ & $\begin{array}{c}0.007 * * * \\
(0.00)\end{array}$ & $\begin{array}{c}0.003^{*} \\
(0.00)\end{array}$ & $\begin{array}{l}0.003 \\
(0.00)\end{array}$ & $\begin{array}{c}0.007 * * * \\
(0.00)\end{array}$ & $\begin{array}{c}0.003^{* *} \\
(0.00)\end{array}$ & $\begin{array}{c}0.006 \text { **** } \\
(0.00)\end{array}$ & $\begin{array}{l}0.002 \\
(0.00)\end{array}$ \\
\hline L.GDP GROWTH & $\begin{array}{l}0.013 \\
(0.01)\end{array}$ & $\begin{array}{l}0.007 \\
(0.01)\end{array}$ & $\begin{array}{c}0.01 \\
(0.02)\end{array}$ & $\begin{array}{l}0.028 \\
(0.02)\end{array}$ & $\begin{array}{c}0.027^{* * *} \\
(0.01)\end{array}$ & $\begin{array}{l}-0.017 \\
(0.01)\end{array}$ & $\begin{array}{l}0.012 \\
(0.01)\end{array}$ & $\begin{array}{c}0.01 \\
(0.01)\end{array}$ \\
\hline L.INFLATION & $\begin{array}{c}0.010^{* * *} \\
(0.01)\end{array}$ & $\begin{array}{l}0.011^{*} \\
(0.01)\end{array}$ & $\begin{array}{l}0.009^{*} \\
(0.01)\end{array}$ & $\begin{array}{c}0.013^{* *} \\
(0.01)\end{array}$ & $\begin{array}{l}0.007 \\
(0.01)\end{array}$ & $\begin{array}{l}0.009 \\
(0.01)\end{array}$ & $\begin{array}{l}0.005 \\
(0.01)\end{array}$ & $\begin{array}{c}0.013^{* * *} \\
(0.01)\end{array}$ \\
\hline L.OIL MINERAL & $\begin{array}{c}-0.048^{* *} \\
(0.02)\end{array}$ & $\begin{array}{c}-0.060 * * \\
(0.02)\end{array}$ & $\begin{array}{c}-0.054 * * \\
(0.03)\end{array}$ & $\begin{array}{c}-0.064 * * \\
(0.03)\end{array}$ & $\begin{array}{c}-0.053^{* * * *} \\
(0.02)\end{array}$ & $\begin{array}{c}-0.072 * * \\
(0.03)\end{array}$ & $\begin{array}{c}-0.042 * * \\
(0.02)\end{array}$ & $\begin{array}{c}-0.059^{*} \\
(0.03)\end{array}$ \\
\hline CONSTANT & $\begin{array}{c}-3.031 * * * \\
(0.37)\end{array}$ & $\begin{array}{c}-4.168 * * * \\
(0.37)\end{array}$ & $\begin{array}{c}-3.343 * * * \\
(0.42)\end{array}$ & $\begin{array}{c}-3.017 * * * \\
(0.50)\end{array}$ & $\begin{array}{c}-3.944 * * * \\
(0.23)\end{array}$ & $\begin{array}{c}-3.656^{* * * *} \\
(0.33)\end{array}$ & $\begin{array}{c}-3.576^{* * * *} \\
(0.41)\end{array}$ & $\begin{array}{c}-4.117 * * * \\
(0.42)\end{array}$ \\
\hline $\mathrm{R} 2$ & 0.0593 & 0.1061 & 0.0463 & 0.0927 & 0.2586 & 0.0637 & 0.1842 & 0.106 \\
\hline Wald Chi2 & $43.5^{* * * *}$ & $75.83 * * *$ & $28.19^{* * *}$ & $49.48 * * *$ & $78.08 * * *$ & $42.82 * * *$ & $64.15^{* * *}$ & $34.04 * * *$ \\
\hline Observations & 1499 & 1616 & 1112 & 784 & 1668 & 1444 & 1415 & 1598 \\
\hline Number of Banks & 359 & 352 & 321 & 248 & 271 & 311 & 205 & 274 \\
\hline Year FE & YES & YES & YES & YES & YES & YES & YES & YES \\
\hline
\end{tabular}


Appendix

Table A1: Sample distribution

\begin{tabular}{lccc}
\hline & $\begin{array}{c}\text { Islamic } \\
\text { Banks }\end{array}$ & Conventional Banks & Total \\
\hline BANGLADESH & 5 & 49 & 54 \\
EGYPT & 1 & 24 & 25 \\
INDONESIA & 8 & 113 & 121 \\
IRAN & 4 & 13 & 17 \\
IRAQ & 6 & 12 & 18 \\
JORDAN & 3 & 11 & 14 \\
KUWAIT & 3 & 14 & 17 \\
LEBANON & 2 & 37 & 39 \\
MALAYSIA & 15 & 29 & 44 \\
MAURITANIA & 2 & 12 & 14 \\
PAKISTAN & 5 & 29 & 34 \\
QATAR & 5 & 8 & 13 \\
SAUDI ARABIA & 3 & 10 & 13 \\
SENEGAL & 1 & 12 & 13 \\
SINGAPORE & 1 & 13 & 14 \\
SUDAN & 7 & 11 & 18 \\
TUNISIA & 1 & 18 & 19 \\
TURKEY & 1 & 45 & 46 \\
UNITED ARAB EMIRATES & 6 & 22 & 28 \\
YEMEN & 3 & 4 & 7 \\
\hline Grand Total & $\mathbf{8 2}$ & $\mathbf{4 8 6}$ & $\mathbf{5 6 8}$ \\
\hline & & & \\
\hline & & & \\
\hline
\end{tabular}


Table A2: Descriptive statistics at the country level

\begin{tabular}{|c|c|c|c|c|c|c|c|c|c|c|c|c|c|c|}
\hline & $\begin{array}{l}\text { DEFAULT } \\
\text { RISK }\end{array}$ & WUI & SIZE & GROWTH & $\begin{array}{l}\text { LOAN } \\
\text { SHARE }\end{array}$ & $\begin{array}{c}\text { NON- } \\
\text { INTEREST } \\
\text { INCOME }\end{array}$ & $\begin{array}{l}\text { COST TO } \\
\text { INCOME }\end{array}$ & LIQUIDITY & $\begin{array}{c}\text { CAPITA } \\
\text { LIZATI } \\
\text { ON } \\
\end{array}$ & $\begin{array}{c}\text { GDP } \\
\text { GROW } \\
\text { TH }\end{array}$ & $\begin{array}{l}\text { INFLATI } \\
\text { ON }\end{array}$ & $\begin{array}{c}\text { OIL } \\
\text { MINERA } \\
\text { L }\end{array}$ & $\begin{array}{l}\text { FOREIG } \\
\text { N BANK } \\
\text { ASSETS }\end{array}$ & $\begin{array}{l}\text { CONCEN } \\
\text { TRATION }\end{array}$ \\
\hline BANGLADESH & -3.70 & -2.85 & 7.18 & 21.09 & 62.57 & 32.46 & 52.76 & 17.64 & 13.89 & 6.45 & 6.73 & 0.09 & 3.00 & 31.51 \\
\hline EGYPT & -3.59 & -1.78 & 8.32 & 17.88 & 36.19 & 23.93 & 45.35 & 24.48 & 10.54 & 3.71 & 13.29 & 6.53 & 22.44 & 59.11 \\
\hline INDONESIA & -3.95 & -2.45 & 7.01 & 20.41 & 63.54 & 18.56 & 62.18 & 18.83 & 16.15 & 5.38 & 5.97 & 3.24 & 25.89 & 40.82 \\
\hline IRAN & -3.26 & -1.88 & 9.55 & 26.52 & 62.35 & 57.98 & 69.58 & 14.12 & 8.74 & 4.46 & 14.33 & 19.53 & & \\
\hline IRAQ & -3.82 & -2.06 & 5.92 & 31.07 & 25.84 & 81.34 & 49.39 & 46.02 & 43.79 & 5.79 & 13.65 & 41.34 & & 66.49 \\
\hline JORDAN & -4.35 & -2.80 & 8.05 & 8.82 & 48.75 & 33.17 & 53.15 & 20.05 & 13.72 & 2.74 & 3.83 & 1.70 & 24.56 & 74.10 \\
\hline KUWAIT & -4.05 & -2.28 & 8.12 & 10.54 & 54.73 & 47.10 & 63.67 & 21.38 & 25.33 & 3.56 & 12.31 & 47.40 & 7.22 & 79.75 \\
\hline LEBANON & -4.47 & -1.28 & 7.75 & 14.37 & 28.24 & 34.25 & 59.90 & 30.90 & 10.41 & 2.90 & 3.92 & 0.00 & 30.22 & 41.25 \\
\hline MALAYSIA & -4.49 & -2.45 & 8.41 & 14.99 & 54.50 & 29.30 & 52.16 & 25.01 & 14.88 & 5.03 & 2.93 & 4.35 & 17.00 & 60.99 \\
\hline MAURITANIA & -4.25 & -2.63 & 4.94 & 18.62 & 52.34 & 53.02 & 83.73 & 26.37 & 23.23 & 3.80 & 6.56 & 31.15 & 5.78 & 71.06 \\
\hline PAKISTAN & -3.72 & -2.37 & 7.53 & 19.42 & 40.50 & 25.56 & 69.40 & 15.32 & 11.94 & 4.12 & 8.21 & 0.73 & 51.56 & 57.33 \\
\hline QATAR & -4.41 & -2.93 & 9.25 & 16.34 & 56.45 & 28.88 & 39.98 & 18.58 & 24.46 & 6.68 & 11.21 & 22.53 & 0.00 & 85.81 \\
\hline SAUDI ARABIA & -4.59 & -2.21 & 10.20 & 9.68 & 60.20 & 33.48 & 41.50 & 16.37 & 19.83 & 3.76 & 9.46 & 35.45 & 0.00 & 55.58 \\
\hline SENEGAL & -3.50 & -2.40 & 6.09 & 19.09 & 57.37 & 54.32 & 70.37 & 16.16 & 10.29 & 4.82 & 1.64 & 1.64 & 92.11 & 54.34 \\
\hline SINGAPORE & -4.62 & -2.80 & 9.38 & 13.41 & 50.62 & 52.16 & 60.07 & 18.23 & 21.56 & 4.68 & 1.47 & 0.00 & 6.11 & 88.35 \\
\hline SUDAN & -3.49 & -1.81 & 6.04 & 31.22 & 34.49 & 64.10 & 56.82 & 28.50 & 17.66 & 3.25 & 22.57 & 8.32 & 10.11 & 84.43 \\
\hline TUNISIA & -3.85 & -1.34 & 7.20 & 13.54 & 61.96 & 43.18 & 59.57 & 26.17 & 11.64 & 2.51 & 4.48 & 4.24 & 28.33 & 39.67 \\
\hline TURKEY & -3.77 & -1.07 & 7.84 & 27.29 & 58.60 & 28.01 & 59.87 & 20.02 & 23.54 & 6.20 & 8.46 & 0.32 & 13.11 & 40.37 \\
\hline UNITED ARAB EMIRATES & -4.17 & -1.78 & 9.23 & 13.69 & 61.36 & 31.72 & 43.66 & 18.43 & 16.96 & 3.80 & 7.67 & 20.32 & 1.00 & 60.81 \\
\hline YEMEN & -3.32 & -2.57 & 6.63 & 15.08 & 13.03 & 43.39 & 63.73 & 37.22 & 11.18 & 7.06 & 17.16 & 11.78 & & \\
\hline
\end{tabular}


Table A3: Correlations

\begin{tabular}{|c|c|c|c|c|c|c|c|c|c|c|c|c|c|c|c|c|}
\hline & (1) & (2) & (3) & (4) & (5) & (6) & (7) & (8) & (9) & (10) & (11) & (12) & (13) & (14) & (15) & (16) \\
\hline (1) DEFAULT RISK & 1 & & & & & & & & & & & & & & & \\
\hline (2) LEVERAGE RISK & $0.9972 *$ & 1 & & & & & & & & & & & & & & \\
\hline (3) PORTFOLIO RISK & $0.7373^{*}$ & $0.6976^{*}$ & 1 & & & & & & & & & & & & & \\
\hline (4) ISLAMIC & -0.002 & -0.01 & $0.0371^{*}$ & 1 & & & & & & & & & & & & \\
\hline (5) WUI & $0.0602 *$ & $0.0629^{*}$ & 0.0144 & $-0.0559 *$ & 1 & & & & & & & & & & & \\
\hline (6) WUI_V2 & $0.0666^{*}$ & $0.0702 *$ & 0.0163 & $-0.0489 *$ & $0.9781 *$ & 1 & & & & & & & & & & \\
\hline (7) WUI_V3 & $0.0736^{*}$ & $0.0774 *$ & 0.0289 & $-0.0798^{*}$ & $0.8237 *$ & $0.8509^{*}$ & 1 & & & & & & & & & \\
\hline (8) SIZE & $-0.1369^{*}$ & $-0.1241^{*}$ & $-0.2928^{*}$ & 0.0065 & $0.0358^{*}$ & $0.0341^{*}$ & -0.0099 & 1 & & & & & & & & \\
\hline (9) GROWTH & $0.1494 *$ & $0.1556^{*}$ & $0.0980^{*}$ & 0.005 & $0.0506^{*}$ & $0.0400^{*}$ & $0.0649 *$ & $-0.2147^{*}$ & 1 & & & & & & & \\
\hline (10) LOAN SHARE & -0.031 & -0.0293 & $-0.0873^{*}$ & -0.0138 & $-0.1149 *$ & $-0.0948 *$ & $-0.0392 *$ & $0.1803^{*}$ & $-0.0695^{*}$ & 1 & & & & & & \\
\hline (11) NON-INTEREST INCOME & $0.1171^{*}$ & $0.1164 *$ & $0.1345^{*}$ & $0.0891 *$ & $0.0547^{*}$ & 0.0158 & 0.0277 & $-0.0952^{*}$ & $0.0540^{*}$ & $-0.3258^{*}$ & 1 & & & & & \\
\hline (12) COST TO INCOME & $0.1601^{*}$ & $0.1441^{*}$ & $0.3496^{*}$ & $0.0392 *$ & 0.0147 & 0.0011 & $0.0376^{*}$ & $-0.3538^{*}$ & $0.0698 *$ & $-0.1442 *$ & $0.1542^{*}$ & 1 & & & & \\
\hline (13) CAPITALIZATION & $-0.1003 *$ & $-0.1209^{*}$ & $0.1169^{*}$ & 0.0264 & 0.0058 & 0.0128 & -0.0003 & $-0.4772 *$ & $0.0735^{*}$ & $-0.1842^{*}$ & $0.1512 *$ & $0.1057 *$ & 1 & & & \\
\hline (14) LIQUIDITY & 0.0016 & -0.0025 & $0.0858^{*}$ & -0.0096 & $0.0751^{*}$ & $0.0669^{*}$ & $0.0560^{*}$ & $-0.3041^{*}$ & $0.1702^{*}$ & $-0.3369^{*}$ & $0.2153^{*}$ & $0.0749^{*}$ & $0.2903^{*}$ & 1 & & \\
\hline (15) GDP GROWTH & $0.0759^{*}$ & $0.0779 *$ & $0.0603 *$ & -0.003 & $-0.1225^{*}$ & $-0.0934 *$ & $-0.0478^{*}$ & $-0.0539 *$ & $0.1322^{*}$ & $0.0749^{*}$ & $-0.0337 *$ & 0.0028 & $0.0580^{*}$ & 0.0057 & 1 & \\
\hline (16) INFLATION & $0.1121^{*}$ & $0.1195^{*}$ & 0.0154 & $0.0858^{*}$ & $0.0426 *$ & 0.0078 & -0.0212 & -0.0054 & $0.0898 *$ & $-0.1185^{*}$ & $0.1345^{*}$ & $-0.0568 *$ & $0.0623^{*}$ & $0.0777 *$ & -0.0223 & 1 \\
\hline (17) OIL MINERAL & $-0.0971 *$ & $-0.0958^{*}$ & $-0.0692 *$ & $0.1548^{*}$ & $0.0371 *$ & $0.0709 *$ & -0.017 & $0.1203^{*}$ & $-0.0708 *$ & $-0.1263^{*}$ & $0.1949 *$ & $-0.0443 *$ & $0.1032^{*}$ & $0.1460^{*}$ & $-0.1913^{*}$ & $0.2246^{*}$ \\
\hline (18) FOREIGN BANK ASSETS & $0.0802^{*}$ & $0.0832^{*}$ & $0.0526^{*}$ & $-0.0851^{*}$ & $0.0404 *$ & -0.0089 & 0.0168 & $-0.2153^{*}$ & 0.0085 & $-0.1205^{*}$ & -0.0306 & $0.1597 *$ & $-0.1639^{*}$ & -0.0277 & $-0.1354^{*}$ & $-0.1764^{*}$ \\
\hline (19) CONCENTRATION & $-0.0950^{*}$ & $-0.0946^{*}$ & $-0.0644^{*}$ & $0.1787^{*}$ & $-0.1365^{*}$ & $-0.2194 *$ & $-0.1291 *$ & $0.1464 *$ & $-0.0752^{*}$ & $-0.1649^{*}$ & $0.2634^{*}$ & $-0.0566^{*}$ & $0.1288^{*}$ & $0.0610^{*}$ & $-0.2016^{*}$ & $0.2682^{*}$ \\
\hline (20) MUSLIM SHARE & $0.1916^{*}$ & $0.1928^{*}$ & $0.1278^{*}$ & $-0.0569^{*}$ & $0.0295^{*}$ & $0.0464 *$ & $0.0588 *$ & $-0.1713^{*}$ & $0.0682 *$ & $0.1318^{*}$ & $-0.0378^{*}$ & $0.0559^{*}$ & $0.0366^{*}$ & $-0.0623 *$ & $0.0794 *$ & $0.2190^{*}$ \\
\hline (21) LEGAL SYSTEM & $-0.0415^{*}$ & $-0.0386^{*}$ & $-0.0558^{*}$ & $0.1767^{*}$ & 0.0057 & $-0.0266 *$ & $-0.0552 *$ & $0.2272 *$ & $-0.0895^{*}$ & $-0.2136^{*}$ & $0.2456^{*}$ & $-0.1026^{*}$ & $-0.0654^{*}$ & $0.0683 *$ & $-0.1939^{*}$ & $0.2139^{*}$ \\
\hline (22) COMMON LAW & -0.0211 & -0.0224 & 0.01 & $0.1343^{*}$ & $-0.3027^{*}$ & $-0.3311^{*}$ & $-0.2683 *$ & 0.0187 & $-0.0441^{*}$ & $-0.0931^{*}$ & $0.1087^{*}$ & -0.0057 & $-0.0395^{*}$ & -0.0204 & 0.026 & 0.0211 \\
\hline (23) CIVIL LAW & 0.0182 & 0.0161 & 0.0146 & $-0.1545^{*}$ & $0.2730^{*}$ & $0.3063^{*}$ & $0.2259^{*}$ & $-0.1243^{*}$ & 0.0215 & $0.0541^{*}$ & $-0.1194 *$ & $0.0303 *$ & $0.0947^{*}$ & $0.0592 *$ & $-0.0296^{*}$ & $-0.0460^{*}$ \\
\hline (24) IMPORTANCE OF RELIGION & $-0.1012 *$ & $-0.1050^{*}$ & $-0.1057^{*}$ & $0.1022 *$ & -0.0144 & -0.0113 & $-0.0958 *$ & $0.3099^{*}$ & $-0.1139^{*}$ & $0.1072 *$ & $0.0394 *$ & $-0.1421^{*}$ & $0.1150^{*}$ & $-0.0673 *$ & $-0.0751^{*}$ & $0.1186^{*}$ \\
\hline (25) LISTED & $-0.0697 *$ & $-0.0655^{*}$ & $-0.1354 *$ & $-0.0587 *$ & $-0.0610^{*}$ & $-0.0612 *$ & $-0.0615^{*}$ & $0.3489^{*}$ & $-0.1247 *$ & $0.1654^{*}$ & $-0.0502^{*}$ & $-0.1049^{*}$ & $-0.1413^{*}$ & $-0.2461 *$ & -0.02 & $0.0581^{*}$ \\
\hline (26) COMMISSION & $0.0449^{*}$ & $0.0458^{*}$ & 0.0294 & 0.0093 & $0.0819^{*}$ & $0.0445^{*}$ & $0.0459^{*}$ & $0.0603^{*}$ & -0.0287 & $-0.1411^{*}$ & $0.4799^{*}$ & 0.0042 & 0.0229 & $0.1182 *$ & $-0.0576^{*}$ & $0.1182^{*}$ \\
\hline (27) TRADING & $0.0617 *$ & $0.0688^{*}$ & -0.0031 & -0.0103 & $-0.1138^{*}$ & $-0.1032 *$ & $-0.1147 *$ & -0.0402 & -0.0246 & $-0.0688 *$ & $0.2463 *$ & 0.0039 & -0.0075 & $0.0694 *$ & -0.0272 & $0.0483 *$ \\
\hline
\end{tabular}


Table A3: Correlations (Continued)

\begin{tabular}{|c|c|c|c|c|c|c|c|c|c|c|c|}
\hline & $(17)$ & $(18)$ & $(19)$ & $(20)$ & $(21)$ & $(22)$ & $(23)$ & $(24)$ & $(25)$ & (26) & (27) \\
\hline (17) OIL MINERAL & 1 & & & & & & & & & & \\
\hline (18) FOREIGN BANK ASSETS & $-0.0863^{*}$ & 1 & & & & & & & & & \\
\hline (19) CONCENTRATION & $0.5998^{*}$ & $-0.1077 *$ & 1 & & & & & & & & \\
\hline (20) MUSLIM SHARE & $-0.1201 *$ & $0.1752^{*}$ & $-0.2596 *$ & 1 & & & & & & & \\
\hline (21) LEGAL SYSTEM & $0.2847^{*}$ & $-0.2755^{*}$ & $0.2734^{*}$ & $0.0427 *$ & 1 & & & & & & \\
\hline (22) COMMON LAW & $-0.3507^{*}$ & $-0.1295^{*}$ & $0.2301 *$ & $-0.2567^{*}$ & $0.2923 *$ & 1 & & & & & \\
\hline (23) CIVIL LAW & $0.3087^{*}$ & $0.1394 *$ & $-0.1374 *$ & $0.2041^{*}$ & $-0.5082^{*}$ & $-0.8230^{*}$ & 1 & & & & \\
\hline (24) IMPORTANCE OF RELIGION & $0.4832^{*}$ & $-0.4117^{*}$ & $0.3736^{*}$ & -0.0026 & $0.3198^{*}$ & $-0.0917^{*}$ & $0.1523^{*}$ & 1 & & & \\
\hline (25) LISTED & 0.0238 & $-0.1049 *$ & $0.0447^{*}$ & $0.1828^{*}$ & $0.1502 *$ & $0.0575^{*}$ & $-0.0625 *$ & $0.2708^{*}$ & 1 & & \\
\hline (26) COMMISSION & $0.1220^{*}$ & $-0.1119^{*}$ & $0.2044^{*}$ & -0.0183 & $0.2144 *$ & $0.0323 *$ & $-0.0404 *$ & $0.1255^{*}$ & -0.0065 & 1 & \\
\hline (27) TRADING & $0.0904 *$ & 0.0046 & $0.0606^{*}$ & $-0.0485^{*}$ & $0.1151 *$ & $0.0749^{*}$ & $-0.0679 *$ & 0.0018 & -0.0314 & 0.0156 & 1 \\
\hline
\end{tabular}


Table A4: Robustness checks for the influence of religiosity

\begin{tabular}{|c|c|c|c|c|c|c|c|c|c|c|c|c|}
\hline & $\begin{array}{c}\text { (1) } \\
\text { (MUSLIM } \\
\text { SHARE } \\
+90)\end{array}$ & $\begin{array}{c}(2) \\
\text { (MUSLIM } \\
\text { SHARE } \\
+90)\end{array}$ & $\begin{array}{c}(3) \\
\text { (MUSLIM } \\
\text { SHARE - } \\
\text { 90) }\end{array}$ & $\begin{array}{l}\text { (4) } \\
\text { (MUSLIM } \\
\text { SHARE - } \\
\text { 90) }\end{array}$ & $\begin{array}{c}(5) \\
\text { (IMPORTANCE } \\
\text { OF RELIGION: } \\
\text { High) }\end{array}$ & $\begin{array}{c}(6) \\
\text { (IMPORTANCE } \\
\text { OF RELIGION: } \\
\text { High) }\end{array}$ & $\begin{array}{c}(7) \\
\text { (IMPORTANCE } \\
\text { OF RELIGION: } \\
\text { Low) }\end{array}$ & $\begin{array}{c}(8) \\
\text { (IMPORTANCE } \\
\text { OF RELIGION: } \\
\text { Low) }\end{array}$ & $\begin{array}{c}(9) \\
\text { (Shari'ah } \\
\text { law) }\end{array}$ & $\begin{array}{c}(10) \\
\text { (Shari'ah } \\
\text { law) }\end{array}$ & $\begin{array}{c}\text { (11) (No } \\
\text { Shari'ah } \\
\text { law) }\end{array}$ & $\begin{array}{c}\text { (12) (No } \\
\text { Shari'ah } \\
\text { law) }\end{array}$ \\
\hline & Islamic & Conv & Islamic & Conv & Islamic & Conv & Islamic & Conv & Islamic & Conv & Islamic & Conv \\
\hline WUI & $\begin{array}{l}-0.077 \\
(0.11)\end{array}$ & $\begin{array}{c}0.137 * * * \\
(0.04)\end{array}$ & $\begin{array}{l}-0.065 \\
(0.07)\end{array}$ & $\begin{array}{l}0.022 \\
(0.03)\end{array}$ & $\begin{array}{l}-0.139 \\
(0.09)\end{array}$ & $\begin{array}{c}0.083 * * \\
(0.03)\end{array}$ & $\begin{array}{l}0.052 \\
(0.07)\end{array}$ & $\begin{array}{c}0.156 * * * \\
(0.04)\end{array}$ & $\begin{array}{c}-0.095^{*} \\
(0.05)\end{array}$ & $\begin{array}{c}0.132 * * * \\
(0.04)\end{array}$ & $\begin{array}{l}0.147 \\
(0.16)\end{array}$ & $\begin{array}{l}0.046 \\
(0.04)\end{array}$ \\
\hline L.SIZE & $\begin{array}{l}0.007 \\
(0.07)\end{array}$ & $\begin{array}{l}0.002 \\
(0.03)\end{array}$ & $\begin{array}{l}-0.077 \\
(0.08)\end{array}$ & $\begin{array}{c}-0.063^{* *} \\
(0.03)\end{array}$ & $\begin{array}{c}0.02 \\
(0.08)\end{array}$ & $\begin{array}{l}0.006 \\
(0.03)\end{array}$ & $\begin{array}{l}-0.109 \\
(0.09)\end{array}$ & $\begin{array}{l}-0.041 \\
(0.03)\end{array}$ & $\begin{array}{l}-0.034 \\
(0.06)\end{array}$ & $\begin{array}{c}-0.073 * * \\
(0.03)\end{array}$ & $\begin{array}{l}0.069 \\
(0.13)\end{array}$ & $\begin{array}{l}0.016 \\
(0.03)\end{array}$ \\
\hline L.GROWTH & $\begin{array}{l}0.003 \\
(0.01)\end{array}$ & $\begin{array}{c}0.004 * * * \\
(0.00)\end{array}$ & $\begin{array}{l}-0.002 \\
(0.00)\end{array}$ & $\begin{array}{l}0.003 * \\
(0.00)\end{array}$ & $\begin{array}{l}-0.003 \\
(0.00)\end{array}$ & $\begin{array}{l}0.002 \\
(0.00)\end{array}$ & $\begin{array}{c}0.008 * * \\
(0.00)\end{array}$ & $\begin{array}{c}0.005 * * \\
(0.00)\end{array}$ & $\begin{array}{l}0.000 \\
(0.00)\end{array}$ & $\begin{array}{c}0.004 * * \\
(0.00)\end{array}$ & $\begin{array}{l}0.001 \\
(0.01)\end{array}$ & $\begin{array}{c}0.003 * * \\
(0.00)\end{array}$ \\
\hline L.LIQUIDITY & $\begin{array}{c}-0.017 * \\
(0.01)\end{array}$ & $\begin{array}{c}-0.002 \\
(0.00)\end{array}$ & $\begin{array}{c}0.013^{*} \\
(0.01)\end{array}$ & $\begin{array}{l}-0.004 \\
(0.00)\end{array}$ & $\begin{array}{l}0.008 \\
(0.01)\end{array}$ & $\begin{array}{l}-0.003 \\
(0.00)\end{array}$ & $\begin{array}{l}-0.006 \\
(0.01)\end{array}$ & $\begin{array}{c}-0.007^{*} \\
(0.00)\end{array}$ & $\begin{array}{l}-0.001 \\
(0.01)\end{array}$ & $\begin{array}{c}-0.007 * * \\
(0.00)\end{array}$ & $\begin{array}{l}0.027 \\
(0.03)\end{array}$ & $\begin{array}{l}0.002 \\
(0.01)\end{array}$ \\
\hline L.LOAN SHARE & $\begin{array}{c}-0.015^{* *} \\
(0.01)\end{array}$ & $\begin{array}{l}-0.005 \\
(0.00)\end{array}$ & $\begin{array}{c}0.014 * * \\
(0.01)\end{array}$ & $\begin{array}{l}0.002 \\
(0.00)\end{array}$ & $\begin{array}{l}0.003 \\
(0.01)\end{array}$ & $\begin{array}{c}-0.006^{*} \\
(0.00)\end{array}$ & $\begin{array}{c}0 \\
(0.01)\end{array}$ & $\begin{array}{l}0.001 \\
(0.00)\end{array}$ & $\begin{array}{l}-0.001 \\
(0.01)\end{array}$ & $\begin{array}{c}0 \\
(0.00)\end{array}$ & $\begin{array}{l}0.019 \\
(0.01)\end{array}$ & $\begin{array}{l}-0.001 \\
(0.01)\end{array}$ \\
\hline L.NON-INTEREST INCOME & $\begin{array}{l}0.004 \\
(0.00)\end{array}$ & $\begin{array}{l}0.004^{*} \\
(0.00)\end{array}$ & $\begin{array}{c}0.010 * * \\
(0.00)\end{array}$ & $\begin{array}{l}0.004 \\
(0.00)\end{array}$ & $\begin{array}{c}0.009 * * \\
(0.00)\end{array}$ & $\begin{array}{l}0.003 \\
(0.00)\end{array}$ & $\begin{array}{l}0.003 \\
(0.00)\end{array}$ & $\begin{array}{c}0.006 * * \\
(0.00)\end{array}$ & $\begin{array}{c}0.004 * * \\
(0.00)\end{array}$ & $\begin{array}{c}0.006^{* * * *} \\
(0.00)\end{array}$ & $\begin{array}{c}0.023 * * \\
(0.01)\end{array}$ & $\begin{array}{l}0.002 \\
(0.00)\end{array}$ \\
\hline L.COST TO INCOME & $\begin{array}{l}0.003 \\
(0.00)\end{array}$ & $\begin{array}{c}0.005^{* * * *} \\
(0.00)\end{array}$ & $\begin{array}{l}0.001 \\
(0.00)\end{array}$ & $\begin{array}{l}0.002 \\
(0.00)\end{array}$ & $\begin{array}{l}0.001 \\
(0.00)\end{array}$ & $\begin{array}{c}0.005 * * * \\
(0.00)\end{array}$ & $\begin{array}{l}0.001 \\
(0.00)\end{array}$ & $\begin{array}{c}0.004 * * \\
(0.00)\end{array}$ & $\begin{array}{l}0.001 \\
(0.00)\end{array}$ & $\begin{array}{c}0.003 * * \\
(0.00)\end{array}$ & $\begin{array}{l}0.013^{*} \\
(0.01)\end{array}$ & $\begin{array}{c}0.005^{* * * *} \\
(0.00)\end{array}$ \\
\hline L.GDP GROWTH & $\begin{array}{l}0.022 \\
(0.02)\end{array}$ & $\begin{array}{l}0.022 \\
(0.01)\end{array}$ & $\begin{array}{l}0.023 \\
(0.03)\end{array}$ & $\begin{array}{c}-0.026^{*} \\
(0.02)\end{array}$ & $\begin{array}{l}0.023 \\
(0.02)\end{array}$ & $\begin{array}{c}0 \\
(0.01)\end{array}$ & $\begin{array}{l}-0.004 \\
(0.04)\end{array}$ & $\begin{array}{l}0.005 \\
(0.02)\end{array}$ & $\begin{array}{l}0.021 \\
(0.02)\end{array}$ & $\begin{array}{l}0.009 \\
(0.01)\end{array}$ & $\begin{array}{l}0.019 \\
(0.07)\end{array}$ & $\begin{array}{l}-0.006 \\
(0.02)\end{array}$ \\
\hline L.INFLATION & $\begin{array}{l}0.004 \\
(0.01)\end{array}$ & $\begin{array}{l}-0.001 \\
(0.01)\end{array}$ & $\begin{array}{c}0.018 * * \\
(0.01)\end{array}$ & $\begin{array}{c}0.016 * * * \\
(0.01)\end{array}$ & $\begin{array}{c}0.018 * * \\
(0.01)\end{array}$ & $\begin{array}{c}0.013 * * * \\
(0.01)\end{array}$ & $\begin{array}{l}0.003 \\
(0.01)\end{array}$ & $\begin{array}{c}-0.012^{*} \\
(0.01)\end{array}$ & $\begin{array}{c}0.017 * * \\
(0.01)\end{array}$ & $\begin{array}{l}0.004 \\
(0.01)\end{array}$ & $\begin{array}{l}-0.029 \\
(0.05)\end{array}$ & $\begin{array}{l}0.018^{*} \\
(0.01)\end{array}$ \\
\hline L.OIL MINERAL & $\begin{array}{l}0.001 \\
(0.01)\end{array}$ & $\begin{array}{l}-0.005 \\
(0.00)\end{array}$ & $\begin{array}{l}0.002 \\
(0.01)\end{array}$ & $\begin{array}{c}-0.008 \\
(0.01)\end{array}$ & $\begin{array}{l}0.002 \\
(0.01)\end{array}$ & $\begin{array}{c}-0.017 * * * \\
(0.01)\end{array}$ & $\begin{array}{c}0 \\
(0.01)\end{array}$ & $\begin{array}{c}0.008 * * \\
(0.00)\end{array}$ & $\begin{array}{l}0.002 \\
(0.01)\end{array}$ & $\begin{array}{l}-0.003 \\
(0.00)\end{array}$ & $\begin{array}{c}-0.244 * \\
(0.15)\end{array}$ & $\begin{array}{l}-0.037 \\
(0.03)\end{array}$ \\
\hline CONSTANT & $\begin{array}{c}-3.616^{* * * *} \\
(0.77) \\
\end{array}$ & $\begin{array}{c}-3.808^{* * *} \\
(0.42) \\
\end{array}$ & $\begin{array}{c}-5.193 * * * \\
(0.83) \\
\end{array}$ & $\begin{array}{c}-3.861 \text { *** } \\
(0.42) \\
\end{array}$ & $\begin{array}{c}-5.360 * * * \\
(0.84) \\
\end{array}$ & $\begin{array}{c}-3.737 * * * \\
(0.42) \\
\end{array}$ & $\begin{array}{c}-3.285^{* * *} * \\
(0.77) \\
\end{array}$ & $\begin{array}{c}-3.842 * * * \\
(0.42) \\
\end{array}$ & $\begin{array}{c}-4.372 * * * \\
(0.59) \\
\end{array}$ & $\begin{array}{c}-3.474 * * * \\
(0.41)\end{array}$ & $\begin{array}{c}-6.711 * * * \\
(1.50)\end{array}$ & $\begin{array}{c}-4.368 * * * \\
(0.51)\end{array}$ \\
\hline R2 & 0.1285 & 0.1651 & 0.1525 & 0.1176 & 0.0193 & 0.1599 & 0.2319 & 0.1591 & 0.022 & 0.1413 & 0.3066 & 0.058 \\
\hline Observations & 151 & 1254 & 325 & 1678 & 279 & 1804 & 197 & 1128 & 406 & 1747 & 70 & 1185 \\
\hline Number of Banks & 33 & 198 & 48 & 276 & 41 & 279 & 40 & 195 & 70 & 295 & 11 & 179 \\
\hline Year FE & YES & YES & YES & YES & YES & YES & YES & YES & YES & YES & YES & YES \\
\hline
\end{tabular}


Table A5: Robustness checks for the influence of the institutional environment

\begin{tabular}{|c|c|c|c|c|c|c|c|c|c|c|c|c|}
\hline & $\begin{array}{c}(1) \\
\text { (COMMON } \\
\text { LAW) }\end{array}$ & $\begin{array}{c}(2) \\
\text { (COMMON } \\
\text { LAW) }\end{array}$ & $\begin{array}{c}\text { (3) } \\
\text { (CIVIL LAW) }\end{array}$ & $\begin{array}{l}(4) \\
\text { (CIVIL } \\
\text { LAW) }\end{array}$ & $\begin{array}{l}\text { (5) } \\
\text { (GCC) }\end{array}$ & $\begin{array}{l}\text { (6) } \\
\text { (GCC) }\end{array}$ & $\begin{array}{c}(7) \\
\text { (non-GCC) }\end{array}$ & $\begin{array}{c}(\mathbf{8}) \\
(\text { non-GCC) }\end{array}$ & (9) (Rich) & (10) (Rich) & (11) (Poor) & (12) (Poor) \\
\hline & Islamic & Conv & Islamic & Conv & Islamic & Conv & Islamic & Conv & Islamic & Conv & Islamic & Conv \\
\hline \multirow[t]{2}{*}{ WUI } & -0.068 & $0.106^{* *}$ & -0.008 & $0.065 * *$ & 0.075 & $0.145 * *$ & -0.029 & $0.067 * *$ & -0.012 & $0.147 * * *$ & -0.096 & 0.03 \\
\hline & $(0.07)$ & $(0.05)$ & $(0.10)$ & $(0.03)$ & $(0.15)$ & $(0.08)$ & $(0.07)$ & $(0.03)$ & $(0.06)$ & $(0.03)$ & $(0.10)$ & $(0.04)$ \\
\hline \multirow[t]{2}{*}{ L.SIZE } & $-0.197 *$ & $-0.110 * *$ & -0.022 & -0.002 & 0.149 & -0.051 & -0.014 & -0.021 & -0.126 & $-0.082^{* * * *}$ & 0.102 & 0.044 \\
\hline & $(0.11)$ & $(0.04)$ & $(0.08)$ & $(0.03)$ & $(0.16)$ & $(0.05)$ & $(0.07)$ & $(0.02)$ & $(0.08)$ & $(0.03)$ & $(0.13)$ & $(0.03)$ \\
\hline \multirow[t]{2}{*}{ L.GROWTH } & 0.000 & 0.003 & 0.002 & $0.003 * * *$ & 0.000 & 0 & 0.002 & $0.004 * * *$ & 0.006 & $0.003 *$ & -0.004 & $0.004 * * *$ \\
\hline & $(0.00)$ & $(0.00)$ & $(0.00)$ & $(0.00)$ & $(0.01)$ & $(0.01)$ & $(0.00)$ & $(0.00)$ & $(0.00)$ & $(0.00)$ & $(0.00)$ & $(0.00)$ \\
\hline \multirow{2}{*}{ L.LIQUIDITY } & 0.005 & $-0.015^{* * * *}$ & -0.013 & 0.002 & -0.005 & 0.009 & 0.006 & -0.005 & -0.007 & 0 & $0.014 * *$ & -0.003 \\
\hline & $(0.01)$ & $(0.00)$ & $(0.01)$ & $(0.00)$ & $(0.02)$ & $(0.01)$ & $(0.01)$ & $(0.00)$ & $(0.01)$ & $(0.00)$ & $(0.01)$ & $(0.00)$ \\
\hline \multirow[t]{2}{*}{ L.LOAN SHARE } & 0.007 & -0.007 & $-0.012 *$ & 0.003 & -0.017 & 0.003 & 0.003 & -0.001 & -0.001 & $0.006^{*}$ & 0.003 & $-0.005^{*}$ \\
\hline & $(0.01)$ & $(0.00)$ & $(0.01)$ & $(0.00)$ & $(0.01)$ & $(0.01)$ & $(0.01)$ & $(0.00)$ & $(0.01)$ & $(0.00)$ & $(0.01)$ & $(0.00)$ \\
\hline \multirow[t]{2}{*}{ L.NON-INTEREST INCOME } & 0.002 & 0.004 & $0.009 * *$ & $0.005 * * *$ & $0.014 * * *$ & 0.007 & $0.005 * *$ & $0.004 * *$ & 0.002 & $0.006 * * *$ & 0.006 & $0.004 *$ \\
\hline & $(0.00)$ & $(0.00)$ & $(0.01)$ & $(0.00)$ & $(0.01)$ & $(0.01)$ & $(0.00)$ & $(0.00)$ & $(0.00)$ & $(0.00)$ & $(0.00)$ & $(0.00)$ \\
\hline \multirow[t]{2}{*}{ L.COST TO INCOME } & 0.000 & 0.001 & 0.001 & $0.005 * * *$ & -0.002 & $0.005^{* * * *}$ & 0.001 & $0.004 * * *$ & 0.001 & $0.004 * *$ & 0.002 & $0.006 * * *$ \\
\hline & $(0.00)$ & $(0.00)$ & $(0.00)$ & $(0.00)$ & $(0.00)$ & $(0.00)$ & $(0.00)$ & $(0.00)$ & $(0.00)$ & $(0.00)$ & $(0.00)$ & $(0.00)$ \\
\hline \multirow[t]{2}{*}{ L.GDP GROWTH } & $0.025^{*}$ & $0.049 * * *$ & 0.013 & -0.01 & 0.009 & 0.026 & 0.019 & -0.005 & & & & \\
\hline & $(0.01)$ & $(0.02)$ & $(0.04)$ & $(0.01)$ & $(0.05)$ & $(0.03)$ & $(0.02)$ & $(0.01)$ & & & & \\
\hline \multirow[t]{2}{*}{ L.INFLATION } & 0.016 & 0.004 & 0.008 & 0.003 & 0.023 & -0.016 & $0.017^{*}$ & 0.004 & 0.01 & -0.005 & $0.021 *$ & $0.016 * * *$ \\
\hline & $(0.01)$ & $(0.01)$ & $(0.01)$ & $(0.01)$ & $(0.04)$ & $(0.02)$ & $(0.01)$ & $(0.01)$ & $(0.01)$ & $(0.01)$ & $(0.01)$ & $(0.01)$ \\
\hline \multirow[t]{2}{*}{ L.OIL MINERAL } & -0.004 & $0.008^{*}$ & -0.006 & -0.004 & 0.002 & -0.002 & $-0.015^{* *}$ & 0.001 & 0.013 & 0.001 & $-0.017 *$ & -0.014 \\
\hline & $(0.01)$ & $(0.01)$ & $(0.01)$ & $(0.00)$ & $(0.02)$ & $(0.01)$ & $(0.01)$ & $(0.01)$ & $(0.01)$ & $(0.00)$ & $(0.01)$ & $(0.01)$ \\
\hline \multirow[t]{2}{*}{ CONSTANT } & $-3.392 * * *$ & $-2.796 * * *$ & $-3.536 * * *$ & $-4.472 * * *$ & $-5.137 * * *$ & $-4.323 * * *$ & $-4.702 * * *$ & $-4.109 * * *$ & $-3.477 * * *$ & $-3.969 * * *$ & $-5.546 * * *$ & $-4.284 * * *$ \\
\hline & $(0.93)$ & $(0.57)$ & $(0.85)$ & $(0.33)$ & $(1.59)$ & $(1.15)$ & $(0.70)$ & $(0.33)$ & $(0.68)$ & $(0.41)$ & $(1.18)$ & $(0.44)$ \\
\hline R2 & 0.2389 & 0.1318 & 0.0671 & 0.1159 & 0.2864 & 0.206 & 0.1056 & 0.1063 & 0.0138 & 0.1238 & 0.0476 & 0.1143 \\
\hline Observations & 245 & 808 & 216 & 2086 & 120 & 375 & 356 & 2557 & 276 & 1443 & 200 & 1489 \\
\hline Number of Banks & 41 & 153 & 36 & 310 & 17 & 49 & 64 & 425 & 54 & 318 & 34 & 278 \\
\hline Year FE & YES & YES & YES & YES & YES & YES & YES & YES & YES & YES & YES & YES \\
\hline
\end{tabular}

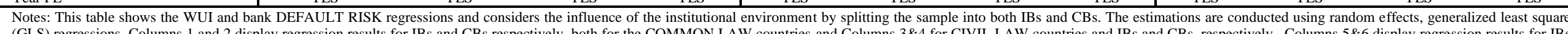

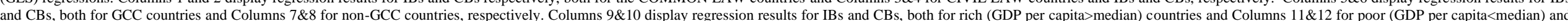
IBs and CBs, respectively. Standard errors are clustered at the bank level and reported in parentheses. ${ }^{*} \mathrm{p}<0.10$, ** $\mathrm{p}<0.05,{ }^{*} * \mathrm{p}<0.010$ 
Table A6: Robustness checks of the cross-sectional analyses on bank heterogeneity

\begin{tabular}{|c|c|c|c|c|c|c|c|c|c|c|c|c|c|c|c|c|}
\hline & \multicolumn{2}{|c|}{ ISLAMIC } & \multicolumn{2}{|c|}{ CONVENTIONAL } & \multicolumn{2}{|c|}{ ISLAMIC } & \multicolumn{2}{|c|}{ CONVENTIONAL } & \multicolumn{2}{|c|}{ ISLAMIC } & \multicolumn{2}{|c|}{ CONVENTIONAL } & \multicolumn{2}{|c|}{ ISLAMIC } & \multicolumn{2}{|c|}{ CONVENTIONAL } \\
\hline & $\begin{array}{l}\text { (1) (High NON- } \\
\text { INTERES } \\
\text { INCOME) }\end{array}$ & $\begin{array}{l}\text { (2) (Low } \\
\text { NON- } \\
\text { INTEREST } \\
\text { INCOME) }\end{array}$ & $\begin{array}{l}\text { (3) (High NON- } \\
\text { INTEREST } \\
\text { INCOME) }\end{array}$ & $\begin{array}{l}\text { (4) (Low } \\
\text { NON- } \\
\text { INTEREST } \\
\text { INCOME) }\end{array}$ & $\begin{array}{c}\text { (5) High } \\
\text { NON- } \\
\text { INTEREST } \\
\text { INCOME- } \\
\text { Trading } \\
\text { Oriented } \\
\end{array}$ & $\begin{array}{c}\text { (6) High } \\
\text { NON- } \\
\text { INTEREST } \\
\text { INCOME- } \\
\text { Commission } \\
\text { and Fee } \\
\text { Oriented } \\
\end{array}$ & $\begin{array}{c}\text { (7) High } \\
\text { NON- } \\
\text { INTEREST } \\
\text { INCOME- } \\
\text { Trading } \\
\text { Oriented } \\
\end{array}$ & $\begin{array}{c}\text { (8) High } \\
\text { NON- } \\
\text { INTEREST } \\
\text { INCOME- } \\
\text { Commission } \\
\text { and Fee } \\
\text { Oriented } \\
\end{array}$ & $\begin{array}{c}\text { (9) } \\
\text { (Large) }\end{array}$ & $\begin{array}{c}(\mathbf{1 0}) \\
\text { (Small) }\end{array}$ & $\begin{array}{l}\text { (11) } \\
\text { (Large) }\end{array}$ & $\begin{array}{l}\text { (12) } \\
\text { (Small) }\end{array}$ & $\begin{array}{c}\text { (13) } \\
\text { (Listed) }\end{array}$ & $\begin{array}{l}\text { (14) } \\
\text { (Non- } \\
\text { listed) }\end{array}$ & $\begin{array}{c}\text { (15) } \\
\text { (Listed) }\end{array}$ & $\begin{array}{l}\text { (16) } \\
\text { (Non- } \\
\text { listed) }\end{array}$ \\
\hline \multirow[t]{2}{*}{ wUI } & $-0.187^{* *}$ & 0.047 & $0.153 * * *$ & 0.026 & -0.127 & -0.2 & $0.175^{* * * *}$ & $0.197 * * *$ & 0.062 & -0.125 & $0.124 * * *$ & 0.07 & -0.155 & $-0.124 *$ & $0.144 * * *$ & 0.027 \\
\hline & $(0.09)$ & $(0.09)$ & $(0.04)$ & $(0.04)$ & $(0.10)$ & $(0.13)$ & $(0.05)$ & $(0.06)$ & $(0.08)$ & $(0.08)$ & $(0.03)$ & $(0.05)$ & $(0.11)$ & $(0.07)$ & $(0.04)$ & $(0.04)$ \\
\hline \multirow[t]{2}{*}{ L.SIZE } & -0.001 & 0.054 & $-0.058 *$ & 0.011 & 0.018 & -0.149 & -0.044 & $-0.101 * * *$ & & & & & 0.022 & 0.049 & -0.029 & 0.049 \\
\hline & $(0.07)$ & $(0.09)$ & $(0.03)$ & $(0.03)$ & $(0.07)$ & $(0.10)$ & $(0.04)$ & $(0.04)$ & & & & & $(0.12)$ & $(0.08)$ & $(0.03)$ & $(0.04)$ \\
\hline \multirow[t]{2}{*}{ L.GROWTH } & -0.001 & 0.007 & 0.001 & $0.004 * * * *$ & -0.001 & -0.005 & 0.001 & 0 & $0.010^{* * *}$ & -0.002 & $0.005^{* *}$ & 0.002 & -0.005 & 0.001 & $0.004 * *$ & 0.002 \\
\hline & $(0.00)$ & $(0.01)$ & $(0.00)$ & $(0.00)$ & $(0.00)$ & $(0.01)$ & $(0.00)$ & $(0.00)$ & $(0.01)$ & $(0.00)$ & $(0.00)$ & $(0.00)$ & $(0.01)$ & $(0.00)$ & $(0.00)$ & $(0.00)$ \\
\hline \multirow[t]{2}{*}{ L.LIQUIDITY } & -0.003 & 0.002 & -0.004 & $-0.006 *$ & -0.003 & 0.01 & 0 & -0.001 & 0.004 & 0 & -0.002 & -0.004 & -0.006 & $0.015^{* * *}$ & -0.004 & $-0.006^{*}$ \\
\hline & $(0.01)$ & $(0.01)$ & $(0.00)$ & $(0.00)$ & $(0.01)$ & $(0.01)$ & $(0.01)$ & $(0.01)$ & $(0.01)$ & $(0.01)$ & $(0.00)$ & $(0.00)$ & $(0.01)$ & $(0.01)$ & $(0.01)$ & $(0.00)$ \\
\hline \multirow[t]{2}{*}{ L.LOAN SHARE } & 0.001 & -0.009 & -0.005 & $-0.006^{*}$ & 0.002 & 0.013 & -0.002 & -0.004 & 0 & -0.007 & $-0.007 * *$ & -0.005 & $-0.019^{* *}$ & $0.010^{*}$ & -0.002 & $-0.007 * *$ \\
\hline & $(0.01)$ & $(0.01)$ & $(0.00)$ & $(0.00)$ & $(0.01)$ & $(0.01)$ & $(0.00)$ & $(0.01)$ & $(0.01)$ & $(0.01)$ & $(0.00)$ & $(0.00)$ & $(0.01)$ & $(0.01)$ & $(0.00)$ & $(0.00)$ \\
\hline \multirow[t]{2}{*}{ L.NON-INTEREST INCOME } & & & & & & & & & $0.011^{* * *}$ & 0.005 & 0.002 & 0.005 ** & 0.002 & $0.008 * * *$ & $0.007^{* * * *}$ & 0.001 \\
\hline & & & & & & & & & $(0.00)$ & $(0.00)$ & $(0.00)$ & $(0.00)$ & $(0.01)$ & $(0.00)$ & $(0.00)$ & $(0.00)$ \\
\hline \multirow[t]{2}{*}{ L.COST TO INCOME } & 0.001 & 0.003 & $0.003^{*}$ & $0.008^{* * * *}$ & 0.002 & -0.001 & $0.003^{*}$ & 0.003 & -0.002 & 0 & $0.008 * * *$ & $0.003 * *$ & 0 & 0.001 & $0.007 * * *$ & 0.001 \\
\hline & $(0.00)$ & $(0.01)$ & $(0.00)$ & $(0.00)$ & $(0.00)$ & $(0.01)$ & $(0.00)$ & $(0.00)$ & $(0.00)$ & $(0.00)$ & $(0.00)$ & $(0.00)$ & $(0.01)$ & $(0.00)$ & $(0.00)$ & $(0.00)$ \\
\hline \multirow[t]{2}{*}{ L.GDP GROWTH } & $0.052^{* * *}$ & 0.004 & 0.003 & 0.014 & $0.060 * *$ & $0.062^{*}$ & -0.002 & 0.024 & 0.029 & 0.002 & 0.024 & -0.025 & 0.047 & 0.01 & 0.007 & 0.001 \\
\hline & $(0.02)$ & $(0.03)$ & $(0.02)$ & $(0.02)$ & $(0.03)$ & $(0.04)$ & $(0.02)$ & $(0.02)$ & $(0.02)$ & $(0.03)$ & $(0.02)$ & $(0.02)$ & $(0.03)$ & $(0.02)$ & $(0.02)$ & $(0.02)$ \\
\hline \multirow{2}{*}{ L.INFLATION } & $0.017^{*}$ & $0.017^{*}$ & 0.005 & 0.005 & $0.019^{*}$ & $0.024 *$ & 0.005 & 0.009 & $0.020^{* * * *}$ & 0.013 & 0.004 & 0.005 & $0.020 * *$ & 0.017 & -0.001 & 0.01 \\
\hline & $(0.01)$ & $(0.01)$ & $(0.01)$ & $(0.01)$ & $(0.01)$ & $(0.01)$ & $(0.01)$ & $(0.01)$ & $(0.01)$ & $(0.01)$ & $(0.01)$ & $(0.01)$ & $(0.01)$ & $(0.01)$ & $(0.01)$ & $(0.01)$ \\
\hline \multirow[t]{2}{*}{ L.OIL MINERAL } & $-0.099 *$ & $-0.186 * * * *$ & $-0.050^{*}$ & -0.043 & -0.039 & -0.029 & $-0.053^{*}$ & $-0.062^{*}$ & $-0.128 * * * *$ & $-0.184 * *$ & $-0.055^{* * *}$ & -0.042 & $-0.137^{* * *}$ & -0.152 & -0.027 & $-0.080 * *$ \\
\hline & $(0.06)$ & $(0.07)$ & $(0.03)$ & $(0.03)$ & $(0.07)$ & $(0.10)$ & $(0.03)$ & $(0.03)$ & $(0.05)$ & $(0.09)$ & $(0.03)$ & $(0.04)$ & $(0.07)$ & $(0.09)$ & $(0.03)$ & $(0.04)$ \\
\hline \multirow[t]{2}{*}{ CONSTANT } & $-4.803 * * *$ & $-4.015^{* * * *}$ & $-2.989 * * *$ & $-4.228 * * *$ & $-4.875 * * *$ & $-4.352 * * *$ & $-3.124^{* * * *}$ & $-2.703 * * *$ & $-4.302 * * *$ & $-4.330^{* * * *}$ & $-3.982^{* * * *}$ & $-3.779 * * *$ & $-3.705 * * *$ & $-6.195 * * *$ & $-4.045 * * *$ & $3.922 * * *$ \\
\hline & $(0.87)$ & $(0.79)$ & $(0.43)$ & $(0.44)$ & $(0.90)$ & $(0.99)$ & $(0.47)$ & $(0.57)$ & $(0.65)$ & $(0.88)$ & $(0.30)$ & $(0.38)$ & $(1.18)$ & $(0.80)$ & $(0.46)$ & $(0.52)$ \\
\hline R2 & 0.0239 & 0.0893 & 0.0755 & 0.0918 & 0.0236 & 0.0014 & 0.0603 & 0.1317 & 0.2202 & 0.0161 & 0.2457 & 0.0853 & 0.2438 & 0.1302 & 0.2182 & 0.0981 \\
\hline Observations & 230 & 232 & 1266 & 1388 & 187 & 118 & 925 & 666 & 261 & 199 & 1409 & 1243 & 162 & 288 & 1253 & 1310 \\
\hline Number of Banks & 57 & 51 & 304 & 304 & 52 & 40 & 269 & 208 & 45 & 45 & 227 & 265 & 26 & 50 & 179 & 224 \\
\hline Year FE & YES & YES & YES & YES & YES & YES & YES & YES & YES & YES & YES & YES & YES & YES & YES & YES \\
\hline
\end{tabular}

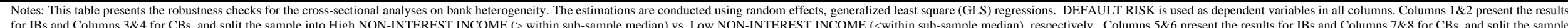

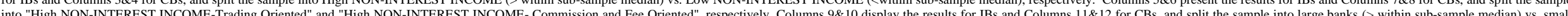
into "High NON-INTEREST INCOME-Trading Oriented" and "High NON-INTEREST INCOME- Commission and Fee Oriented", respectively. Columns $9 \& 10$ display the results for IBs and Columns 11 \& 12 for CBS, and split the sample into large banks ( within sub-sample median) vs. small
banks ( within sub-sample median), respectively. Columns $13 \& 14$ present the results for IBs and Columns $15 \& 16$ for CBS, and split the sample into LISTED banks vs. non-LISTED banks. Standard errors are clustered at the bank level and reported in parentheses. * p $<0.10$, ** p $<0.05$, *** p<0.010 